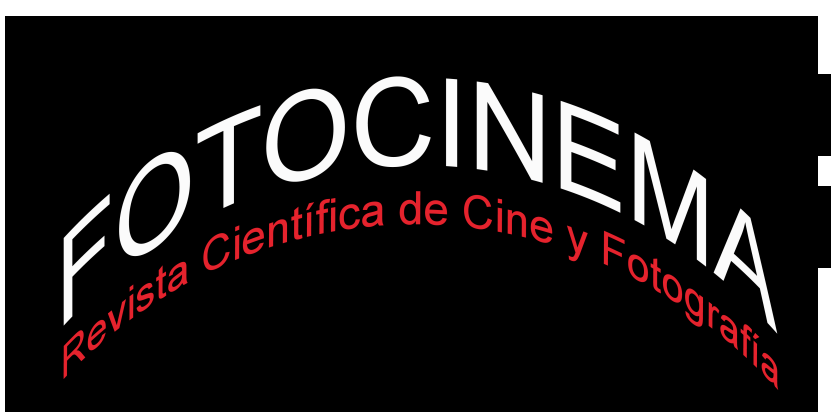

\title{
GERDA TARO Y LOS ORÍGENES DEL FOTOPERIODISMO MODERNO EN LA GUERRA CIVIL ESPAÑOLA
}

\author{
GERDA TARO AND THE ORIGINS OF MODERN \\ PHOTOJOURNALISM IN THE SPANISH CIVIL WAR
}

\author{
Lorna Beatriz Arroyo Jiménez \\ Universitat Jaume I, España \\ LornaBeatriz.Arroyo@uji.es \\ Hugo Doménech Fabregat \\ Universitat Jaume I, España \\ hdomenec@com.uji.es
}

\begin{abstract}
Resumen:
El hallazgo en México durante el año 2007 de más de 4.000 negativos inéditos de la Guerra Civil Española pertenecientes a Robert Capa (Endre Ernö Friedmann), David Seymour (David Szymin, "Chim") y Gerda Taro (Gerda Pohorylle) ha puesto definitivamente en valor el trabajo de esta última, la primera fotoperiodista fallecida en el frente de acción por documentar desde primera línea la guerra de España. El presente trabajo revisa el momento fotográfico de la Guerra Civil Española a partir del trabajo de Gerda Taro a razón del valor y significación de sus fotografías. Para ello, se han estudiado 716 originales de la fotógrafa en diferentes soportes (película negativa de $35 \mathrm{~mm}$ y $6 \times 6 \mathrm{~cm}$, copias por contacto, copias de época y modernas), y se han analizado pormenorizadamente algunas de estas fotografías mediante un método que ha permitido obtener conclusiones definitivas sobre el conjunto de su obra. Los resultados apuntan a que la práctica fotográfica de Gerda Taro en la guerra de España contribuyó a la redefinición del concepto de fotoperiodismo en occidente.
\end{abstract}

\begin{abstract}
:
The discovery in Mexico in 2007 of more than 4,000 unpublished negatives from the Spanish Civil War, owned by Robert Capa (Endre Ernö Friedmann), David Seymour (David Szymin, "Chim") and Gerda Taro (Gerda Pohorylle) has in particular shown the importance of the latters body of work. Taro is considered to be the first photographer to die during a war, whilst working on the front line of the Spanish Civil War. This paper reviews Taro's photographs that capture this important moment in time, in Taro's own, unique photojournalistic style. To do this, 716 original photographs were studied across different media, $(35 \mathrm{~mm}$ negative films, $6 \times 6 \mathrm{~cm}$ contact prints and enlargements), some of which have been thoroughly analyzed by a method that has led to precise conclusions about the body of work. The results show that Gerda Taro's work during the Spanish Civil War contributed to the redefinition of the concept of photojournalism in the West.
\end{abstract}

Palabras clave:

Gerda Taro; Robert Capa; Fotoperiodismo; Vanguardias Históricas; Guerra Civil Española; Análisis fotográfico.

Keywords:

Gerda Taro; Robert Capa; Photojournalism; Historical Vanguards, Spanish Civil War, Analysis photographic. 


\section{Introducción}

El trabajo fotográfico realizado por la fotógrafa Gerda Taro durante la Guerra Civil Española sitúa a esta autora como figura pionera del incipiente fotoperiodismo moderno. A efectos fotográficos Guerra Civil Española marcó un punto de inflexión en la era de la comunicación visual de los sucesos que anticipó lo que más tarde detentaría la televisión. La Guerra Civil Española, como sería la Guerra de Vietnam a efectos televisivos, fue la primera guerra intensamente documentada en el sentido de que las imágenes no sólo pretendieron ofrecer un testimonio visual de los hechos, sino más bien de "incidir en la conciencia de una masa de espectadores" (Newhall, 1983: 314). Cámaras como la Rolleiflex y la Leica permitieron que los fotógrafos que documentaron esta guerra pudieran tomar por primera vez fotografías desde la primera línea de batalla con un estilo capaz de poner en práctica técnicas y encuadres novedosos, influidos por las prácticas y teorías que postulaban las vanguardias artísticas en el contexto europeo de los años treinta. De este modo, algunos de ellos no solo trataron de contar lo que sucedía en España, sino más bien de contribuir con su trabajo a modificar el curso de las políticas europeas, enfrentadas definitivamente en la Segunda Guerra Mundial. Del compromiso de estos fotógrafos con el carácter ético que representaban, en un momento de avances técnicos sin precedentes en la captura y difusión de imágenes, surgió un modelo de fotografía que marcaría un antes y un después en la era del fotoperiodismo, en general, y de guerra, en particular.

Sin duda, la figura que ha quedado asociada con mayor fuerza al momento fotográfico de la Guerra Civil Española ha sido la de Robert Capa, en torno al cual desde entonces comenzó a forjarse lo que se ha dado a llamar "el mito del reportero de guerra" (Chéroux, 2001: 307). Es bastante menos conocido, sin embargo, el nombre de Gerda Taro, con quien Capa ${ }^{1}$ compartió jornadas de trabajo, cámaras fotográficas, reportajes de prensa y la firma común

${ }^{1}$ De hecho, antes de conocer a Gerda Taro, Robert Capa no se llamaba Robert Capa sino Endre Ernö Friedmann. El personaje Capa fue ideado por la pareja en París poco antes de viajar a España para aumentar el precio de venta de las fotografías que realizaban y vendían en común con esta firma. 
"Photo Capa" hasta que Gerda, poco antes de morir, comenzó a reivindicar un lugar propio en la profesión distinguiendo su trabajo del de Capa con el uso de la firma independiente "Photo Taro". Aun así, muchas de sus fotografías fueron atribuidas a su compañero, cuya reputación lograría definitivamente eclipsar el valor del trabajo de esta fotoperiodista, comprometida con el tema de su obra hasta el punto de arriesgar mortalmente su vida con tal de proporcionar un testimonio visual tan convincente como impactante. Por todo ello, este trabajo centra su atención en la obra de Gerda Taro a razón del modelo de fotografía que impondrá esta autora. Un modelo que radiografía idóneamente el importante momento fotográfico que lo enmarca por varias razones.

En primer lugar, porque se trata de un trabajo fotoperiodístico cuyo tema absoluto es la Guerra Civil Española. Sus fotografías, realizadas inicialmente con una cámara Rolleiflex y después con una Leica, captaron con gran proximidad emocional al tema y un novedoso estilo, en ocasiones muy próximo a la fotografía de la Nueva Visión, el día a día de los civiles y soldados. Precisamente su cobertura de la guerra de España junto al Cuerpo del Ejército en vanguardia fue lo que la llevó a una muerte en ciernes que encabezaría la gran lista de los más destacados fotoperiodistas de guerra caídos durante el ejercicio de su profesión ${ }^{2}$. Asimismo, sus imágenes de la población en huida son testimonio del nacimiento gráfico del refugiado moderno (Faber, 2011), e igual de inquietantemente novedosas resultan sus dramáticas fotografías de hombres, mujeres y niños fallecidos durante los primeros ataques bélicos que atentaban contra la población civil de un país. Por otro lado, también cabe destacar la materia que afecta a la cuestión de la autoría, un tema de escaso interés para el fotoperiodismo previo al del momento de la Guerra Civil, pero fundamental a partir de éste, donde el autor empírico de las imágenes ya ocupa un lugar propio en el ámbito de la prensa escrita. Este aspecto también es fiel reflejo de la trayectoria de la

${ }^{2}$ Gerda Taro, cuya crónica de su muerte anunció Life el 16 de agosto de 1937 como: "La primera mujer-fotógrafo muerta en acción”, falleció casi dos décadas antes que sus compañeros fotoperiodistas Robert Capa (1913-1954) y "Chim" (1911-1956), también caídos en frentes de guerra mientras cubrían conflictos armados. 
fotoperiodista, que al final de su vida comenzó a reivindicar la autoría de su trabajo con el uso de la firma independiente "Photo Taro", mientras inicialmente, o bien sus imágenes aparecían publicadas sin firmar, o bajo la identidad del sello aglutinante "Photo Capa". Por todo ello, y aquí reside el núcleo de nuestra hipótesis, la fotografía de Gerda Taro es ejemplo paradigmático del importante momento que la enmarca, el de la Guerra Civil Española, definido en términos fotográficos como la "línea divisoria entre los principales modelos de fotografía, desarrollados en las dos guerras mundiales" (Fontcuberta, 1988: 172).

El objetivo principal de este artículo se centra en identificar los principales rasgos de la obra fotográfica de Gerda Taro a través del estudio de casos significativos. Con ello se pretende demostrar su eficacia para el importante momento fotográfico donde se desarrollan y al que favorecen estas prácticas. Para alcanzar estos propósitos seguiremos los siguientes pasos.

En primer lugar se propone una aproximación al tema de la fotografía de la Guerra Civil Española que vincula el arte y la fotografía de las primeras vanguardias con los inicios del fotoperiodismo moderno.

En segundo, se examina este momento fotográfico a partir de las posibilidades que brinda en el ecuador de la década de los treinta el contexto, la técnica y la mirada fotográfica, tres variables fundamentales que, convenientemente combinadas, explican el modelo fotográfico desarrollado durante la Guerra Civil, un modelo que marcará un antes y un después en el ámbito del fotoperiodismo.

En tercero, se comentan los principales rasgos del conjunto de la obra de Gerda Taro, derivados del estudio de su obra y los resultados de los análisis pormenorizados de algunas de sus fotografías.

Por último se exponen las principales conclusiones. 


\section{Interferencias estéticas entre los diferentes lenguajes de los años 30}

Para tratar con rigor el tema destacado resulta necesario realizar una revisión de los procesos de expresión e innovación que la fotografía del periodo moderno fue capaz de asimilar de los anteriores o lindantes. Luego, cabe partir de la Primera Guerra Mundial como el momento en el que surgen innovadoras teorías y prácticas artísticas que afectan a lo fotográfico a propósito de los cambios que experimenta la historia occidental. El arte de la vanguardia se explica a partir de la inflexión sociohistórica de la Primera Guerra Mundial y la Revolución de Octubre, y este es, precisamente, el momento en que emerge la fotografía moderna (Sougez, 2007: 302). Como sucede con todo proceso de creación, también la nueva fotografía participa de un marco sociohistórico, político, artístico y cultural al que no puede ser ajena, y en este ámbito se haya íntimamente vinculada a los demás lenguajes expresivos con los que cohabita, participa, afecta y le afectan.

En este nuevo panorama de interconexión entre la imagen técnica y la plástica3 ${ }^{3}$ la vanguardia hará hincapié en la preocupación por el intento de simplificar los elementos compositivos y en la definición de estructuras esencialmente geométricas. El interés por la geometría, la plasmación del movimiento, las perspectivas inusuales y la utilización de nuevas técnicas a las expectativas del azar marcarán el nuevo rumbo de la fotografía a partir de figuras claves como los hermanos Bragaglia, László Moholy-Nagy, Alexandre Rodchenko, André Kertész y Henri Cartier-

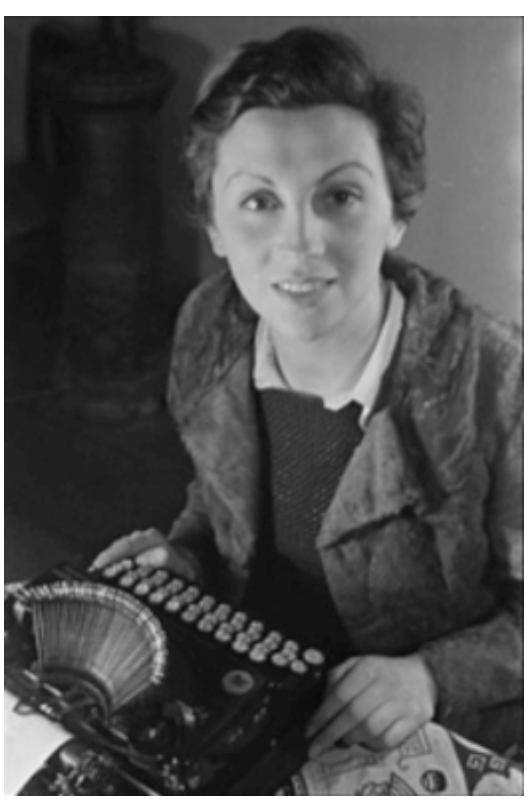

F1. Gerda Taro, París, 1935. Fotografía de Fred Stein (C) ICP.

\footnotetext{
3 Para profundizar en la cultura visual que aporta la imagen tecnológica véase: HUYSSEN, Andreas: "La dialéctica oculta: vanguardia-tecnología-cultura de masas", en Después de la gran división. Modernismo, cultura de masas, posmodernismo, Adriana Hidalgo, Buenos Aires, 2002.
} 
Bresson, entre otros. El nuevo planteamiento para la imagen técnica, facilitado por la manejabilidad de las nuevas cámaras fotográficas, modificará la visión tradicional de la realidad a través de la incorporación de nuevas formas de expresión que darán como resultado una visión inusual y más personalizada del mundo. Esta suma de apreciaciones, que podrían considerarse propias del ámbito artístico, iba a ser susceptible de absorción en modalidades fotográficas insospechadas, tales como el fotoperiodismo de guerra, cuando la fotografía, siempre interesada por lo comúnmente denominado "inaccesible” (Berger, 2000: 7), se ocupa de la situación española con motivo del inicio de la guerra.

De este modo se ha planteado una aproximación a la fotografía de la Guerra Civil Española que vincula el arte y la fotografía de las primeras vanguardias con los inicios del fotoperiodismo moderno en España. Pero, con toda probabilidad, la mejor manera de ilustrar esta idea es mediante ejemplos concretos, como el de Henri Cartier-Bresson, reportero gráfico en España, maestro del reportaje y uno de los fotógrafos más influyentes del siglo XX. Este fotógrafo al ocaso de su vida dijo: "es al surrealismo al que debo fidelidad, ya que me enseñó a dejar que el objetivo fotográfico recorriera las huellas del inconsciente y del

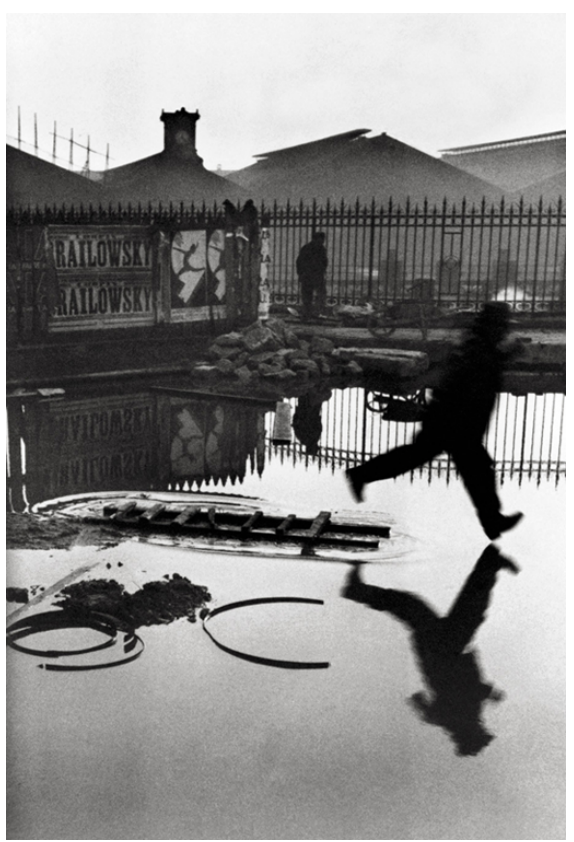

Figura 2. Detrás de la estación de SaintLazare, París, 1932. Fotografía de Henri Cartier-Bresson. azar" (Cartier-Bresson, 2011: 91). La Leica fue el otro elemento al que Cartier-Bresson rindió máxima lealtad, una cámara que le llevaría a la creación de una estética donde lo más importante era prestar atención a lo que pasaba alrededor, ser receptivo al azar y a la revelación. Gracias a ella nació lo que el autor bautizó como la teoría del instante decisivo (Cartier-Bresson, 2011: 15), una metáfora de la caza que se explica como la comunión entre contenido y forma que el fotógrafo debe descubrir y capturar en un instante preciso, tal y como sucede en una de sus 
instantáneas más conocidas: Detrás de la estación de Saint-Lazare, París, 1932, fotografía en la que aparece un hombre saltando un gran charco en sintonía con la figura que hay tras él acompañando a la palabra Railowsky. Son numerosos los aspectos que podrían comentarse de esta imagen; sin embargo, el más destacable es el del instante registrado, pues un segundo antes o después de su captura la imagen ya no expresaría lo mismo, del mismo modo que sucede con otro de los ejemplos gráficos por antonomasia: Muerte de un miliciano. Esta fotografía marcó un punto de inflexión en el reportaje bélico moderno, ya que por primera vez se capturaba y mostraba el supuesto preciso instante de la muerte de un hombre durante una batalla, cuando hasta entonces las fotografías de guerra solo habían logrado mostrar los momentos previos o posteriores a este instante.

Por tanto, antes de seguir avanzando conviene subrayar lo que se avista en el trasfondo de este ejercicio de comparación, es decir, el modo en que, retrospectivamente, puede comprobarse cómo las tendencias expresivas de

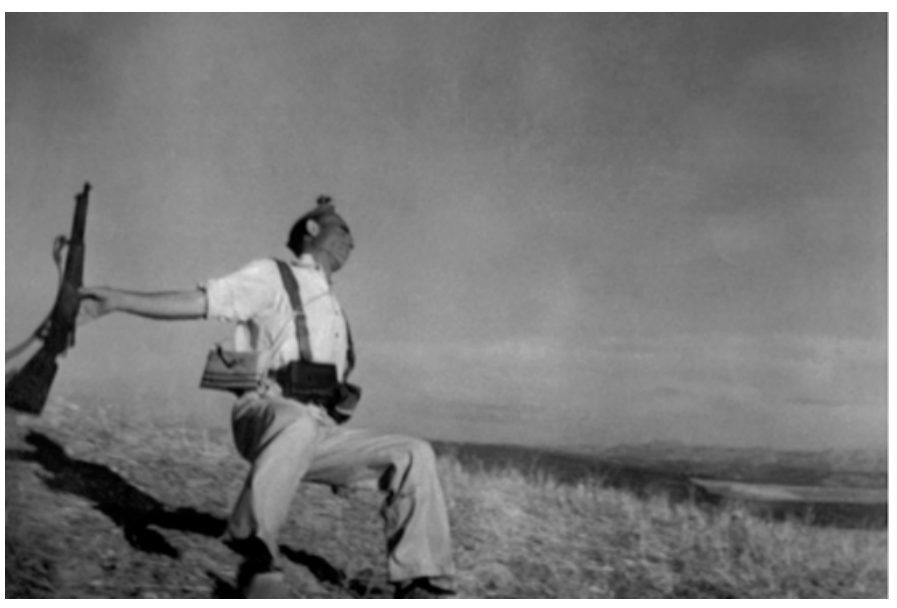
toda una época convergen. Para el caso de la fotografía

F3. Muerte de un miliciano, Córdoba, 1936. Fotografía de Robert Capa (C) ICP.

de entreguerras consistió en el regreso a un nuevo realismo que estuvo íntimamente ligado a las tendencias políticas, culturales y artísticas de toda una época. En Francia, por ejemplo, el movimiento surrealista enlazó los hechos reales de la vida con el inconsciente y la intuición, mientras que en Estados Unidos un nuevo realismo, riguroso y documental, trataba de reflejar la crisis del país tras el crack del 29 a través de la expresión escrita y visual con obras como las de Hemingway o los fotógrafos de la FSA, respectivamente. Por su parte, la nueva realidad de la vida soviética se inscribió en un tipo muy concreto de cine y fotografía que puso a su servicio 
la creación de una nueva sociedad, una idea que también había desarrollado a efectos artísticos la Bauhaus en Alemania, mientras en este mismo lugar el movimiento de la Nueva Objetividad se expresaba mediante un estilo que pretendía ser lo más objetivo posible. Paralelamente "el periodismo se lanzaba al reportaje sobre la vida del hombre de la calle. El público reclamaba hechos exactos" (Freund, 2008: 24).

En definitiva, lo se pretende señalar es que había surgido una nueva forma de ver a la que el documentalismo gráfico, favorecido por los avances técnicos, no iba a ser indiferente. Y cuando comienza la Guerra Civil Española, esa nueva forma de ver se traslada al campo de acción español para dar testimonio de un conflicto que traspasaba sus propias fronteras geográficas, pues esta guerra interna también fue la primera gran lucha donde se enfrentaron las fuerzas democráticas y las potencias totalitarias fascistas emergentes en Europa (Preston, 2005). Todo ello explica que tanto la fotografía como las empresas periodísticas que dieron uso a las imágenes generadas en el marco español libraran su particular batalla, la de la información, bajo el propósito de influir en la opinión pública y, con ello, en el devenir histórico.

\section{El contexto, la técnica y la mirada: el fotoperiodismo de la Guerra Civil Española}

\subsection{El contexto}

La Guerra Civil Española fue una disputa que esclareció a vida o muerte diversos conflictos entrelazados, separados por corrientes antagónicas, y los expuso al mundo a través de imágenes fotográficas. El conflicto español se convirtió a un tiempo en el campo de batalla de las ideologías enfrentadas en Europa, en el terreno de experimentación de nuevas técnicas de destrucción bélica y en un laboratorio de la información gráfica. Por todo ello, historiadores y analistas coinciden en considerar esta guerra interna como el prólogo o inicio de la Segunda Guerra Mundial, 
En un momento marcado por el irresistible ascenso del nacionalsocialismo de Hitler, la guerra española concitó pronto el interés del mundo entero, que veía en ella una primera batalla entre la democracia y los fascismos. (...) Este carácter ejemplar, emblemático y premonitorio de la Guerra Civil Española atrajo a miles de corresponsales de todos los medios del mundo, conscientes de que con la crónica de los hechos bélicos se produciría un impacto profundo en la conciencia de sus lectores (López, 2005, p. 297).

La gran cobertura de esta guerra civil activó las conciencias extranjeras, lo que provocó un movimiento de solidaridad insólito en ayuda de un pueblo sellado por sus diferencias internas irremediables. Por tanto, el suceso estuvo íntimamente ligado al hecho de que el conflicto bélico español sobreviene en un momento crucial que coincide con el desarrollo de la prensa y las revistas ilustradas en Europa y América. Estas publicaciones periódicas difundieron la guerra de España alrededor del mundo, pero la noticia caló especialmente en los ambientes progresistas europeos, donde la mayoría de intelectuales entendieron que el combate contra las ideas fascistas que amenazaban la democracia comenzaba con la lucha contra el fascismo en España. Prueba de ello fue la llegada del gran número de intelectuales, artistas y fotógrafos extranjeros que participaron activamente en el suceso español: George Orwell, Tina Modotti, Erika Mann, Anna Seghers, Kati Horna, Martha Gellhorn, Margaret Michaelis, Louis Aragon, Max Aub, André Malraux, Ernest Hemingway, John Dos Passos, Léon Blum, Arthur Koestler, Louis Ficher, Jay Allen, Mijaíl Kolstov, Robert Capa, Gerda Taro y “Chim” suponen una minoría especialmente representativa del atractivo plantel que atendió y fijó la Guerra Civil Española en el imaginario colectivo4. Muchas veces se ha explicado la razón de la nutrida representación extranjera que llegó a España en apoyo a la República, pero pocas de manera tan concisa y clara como la fotógrafa italiana Tina Modotti a través de la voz de Mura, la mujer que

\footnotetext{
4 La presencia de esta élite sobrevino a la creación del mito de la España republicana, cuestión de gran utilidad política dado que la ideología de izquierdas logró de la cultura y las artes la identificación con estas ideas. De hecho, teóricos como el hispanista británico Robert Stradling sugieren que incluso la vinculación actual y casi instantánea de las artes con las ideas de izquierda es una herencia de entonces (Stradling, 2003).
} 
Hemingway haría famosa como el personaje de "la guerrillera María” en su novela Por quién doblan las campanas (1940):

Más tarde, cuando supe que no era española, le pregunté que por qué había venido a nuestro país, por qué arriesgaba la vida por nosotros. Me miró y dijo que, para ella, no había más que una cosa en la vida: la lucha contra el fascismo. Me dijo que esto no era, para ella, una cuestión teórica, sino consecuencia de todo lo que ella misma había sufrido a causa del fascismo. Que en su patria no podía luchar y que por eso España era la última trinchera que le quedaba. Nunca olvidaré lo que me dijo en aquella ocasión: "Si perdemos aquí, perdemos en todas partes” (en Barckhausen, 1998, p. 140).

Este testimonio novelado arroja luz sobre la razón general de los extranjeros que decidieron unir fuerzas para combatir el fascismo en España, algunos mediante el relato de sus impresiones y otros, como Modotti y Orwell, también como sanitarios o combatientes. Pero cabe pensar que todos acudieron al país con la certeza de que asistirían a un conflicto en el que se iba a dirimir el modelo ideológico y político del futuro europeo. Luego, más que de asumir un papel testimonial en la historia se trataba de participar en su devenir. Según lo explica A. Herbert L. Matthews, entonces cronista del New York Times:

Todos los que vivimos la Guerra Civil Española nos conmovimos y nos dejamos la piel... siempre me pareció falsedad e hipocresía en quienes afirmaban ser imparciales; y locura, cuando no una estupidez rotunda, en los editores y lectores que exigían

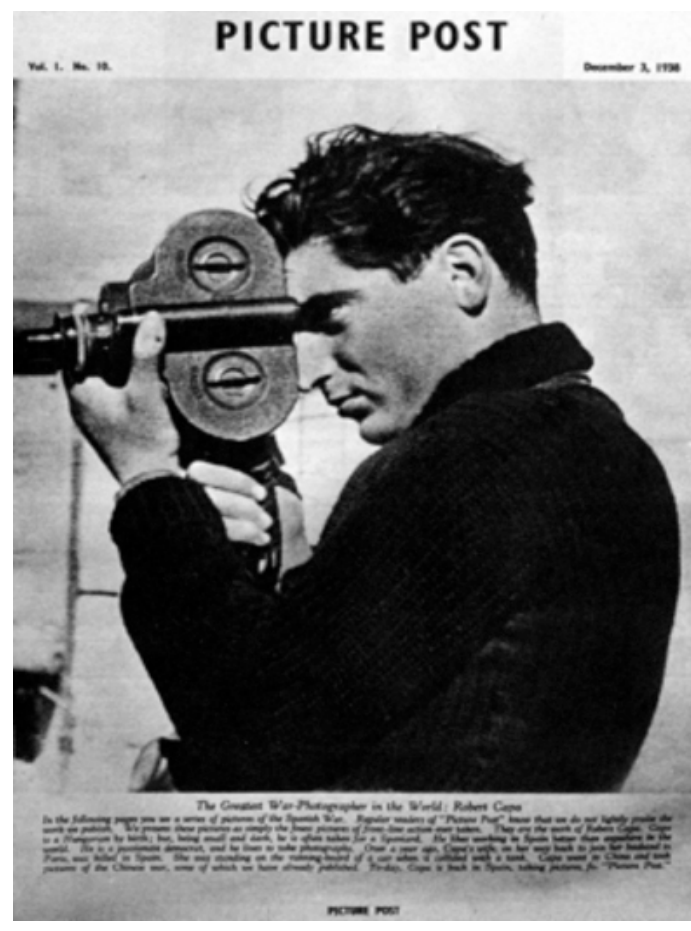

F4. Robert Capa, frente de Segovia. Finales de mayo, principios de junio de 1937. Fotografía publicada el 3 de diciembre de 1938 en página 13 del $\mathrm{n}^{0} 10$ de Picture Post sobre el pie de foto "The best war photographer in the world: Robert Capa" ("El mejor fotógrafo de guerra del mundo: Robert Capa”). Fotografía de Gerda Taro (C ICP. objetividad o imparcialidad a los corresponsales que escribían sobre la guerra... al condenar la imparcialidad se 
rechazan los únicos factores que realmente importan: la sinceridad, la comprensión y el rigor (en Preston, 2007, p. 21).

Más de 70 años después, la periodista Maruja Torres avanzaba en el mismo sentido:

Cierto. Puedes escribir sobre los últimos acuerdos, las gestiones de paz, las conversaciones entre mediadores, lo que te ha contado un jefe militar (...) No es la verdad. La verdad es lo que ves y sientes y hueles y tocas y lloras y sufres, la verdad tiene nombre, tiene rostro, tiene heridas, tiene rencor, tiene pena, tiene esperanza, tiene derrota. La verdad son las víctimas. Y eso es lo que debes contar, y lo que te lacera, y lo que va cambiándote, lo que va sacándote de tu refugio de noticias domadas y reencuadradas (Torres, 1999, p. 229).

Estos argumentos basados en la expresión para el periodismo escrito, se concentran en lo fotográfico en el más famoso aforismo atribuido a Robert Capa: "Si tu foto no es lo bastante buena, es que no estabas lo bastante cerca”. Y esta cercanía, tanto física como emocional, fue, en definitiva, la razón que explica la arriesgada actividad y los consecuentes resultados fotográficos y vitales- de la fotógrafa alemana Gerda Taro en España.

\subsection{La técnica}

Desde el punto de vista técnico, la Guerra Civil Española también fue un lugar de experimentación del que surgieron nuevas fórmulas de reportajes gráficos, dado que es entonces cuando la figura del corresponsal gráfico se posiciona ideológicamente y puede acceder a lugares donde nunca antes había conseguido llegar fotográficamente. Como señala el fotohistoriador Publio López Mondéjar:

Las fotografías de guerras anteriores eran sólo tangencialmente ilustrativas, y carecían de ese sello de autor que tuvieron ya en España. Y no sólo por las limitaciones mecánicas que debían superar los reporteros, sino porque faltaba en ellos ese sentimiento de solidaridad, de identificación, de pasión $-y$ también de compasión- que comienza a darse de un modo determinante en la Guerra Civil Española. La vieja visión estética y fríamente profesional deja 
paso a una visión ética, participativa y solidaria, que anuncia una nueva etapa de la comunicación fotográfica marcada por la emoción, la exaltación y la militancia del fotógrafo (López, 2005, p. 298).

Durante la Primera Guerra Mundial la cámara habitualmente usada fue la Graflex, con fuelle y placas de cuatro a cinco pulgadas. Su pesadez dificultaba la tarea del fotógrafo y el margen de maniobra en situaciones de peligro era muy limitado, por lo que obtener fotografías espontáneas

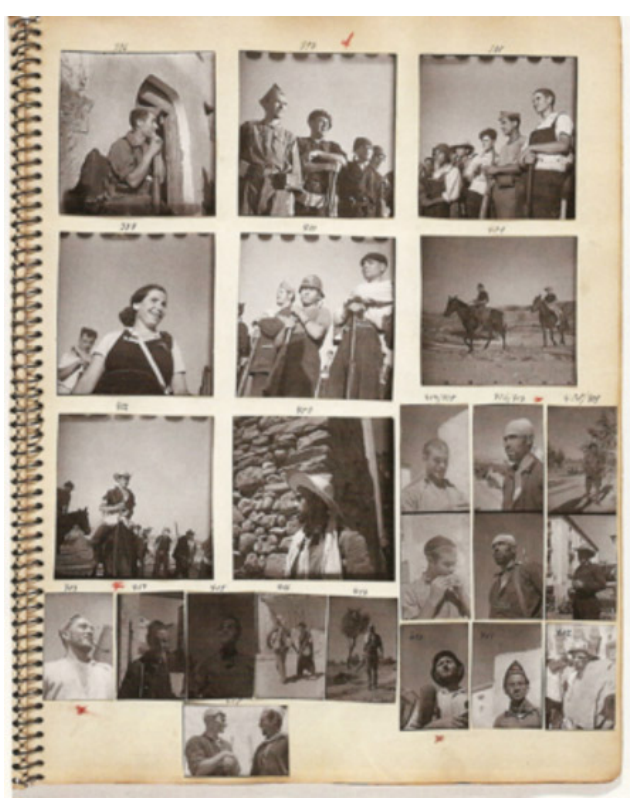

F5. Uno de los cuadernos de trabajo de Robert Capa y Gerda Taro con copias por contacto en $24 \times 36 \mathrm{~mm}$ y $6 \times 6 \mathrm{~cm}$. Fotografías realizadas en Santa Eulalia, Huesca, en agosto de 1936 (C) ICP resolverse con la oferta del gran formato. Este problema para la instantánea fue definitivamente resuelto con el uso del formato pequeño y el negativo en rollo $24 \times 36 \mathrm{~mm}$ que, entre otros, ampliaba la carga de la máquina a 36 disparos seguidos. La conocida como película de $35 \mathrm{~mm}$ fue la utilizada en una cámara que marcaría un hito en la era de las cámaras fotográficas: la Leica.

El uso de la cámara Leica supuso un cambio radical en el modo de mirar los fotógrafos, pues con ella ya no tenían que cargar con 15 kilos de peso ni mirar desde arriba para capturar las imágenes. Esta cámara, empleada por Gerda Taro durante su momento profesional decisivo, comenzó a popularizarse a principios de la década que enmarca la Guerra Civil Española, por lo que en este contexto los reporteros ya pueden aproximarse al objeto fotográfico y tomar imágenes en condiciones desfavorables de luz y movimiento. Ante esta 
suma de oportunidades, los fotógrafos, como los soldados, asistirán a las batallas a campo abierto arriesgándose a morir con tal de realizar su tarea, lo que explica, en palaras de Frank Hanighen, entonces corresponsal del Washington Post, que la guerra de España marque "el comienzo de una nueva etapa, la más peligrosa con diferencia de toda la historia del reportaje periodístico" (en Preston, 2007: 18). Este nuevo modelo de fotografía, desarrollado en un momento en el que las revistas gráficas estaban en auge, ha permitido definir la guerra de España como "cuna del fotoperiodismo moderno" (Sontag, 2003: 43).

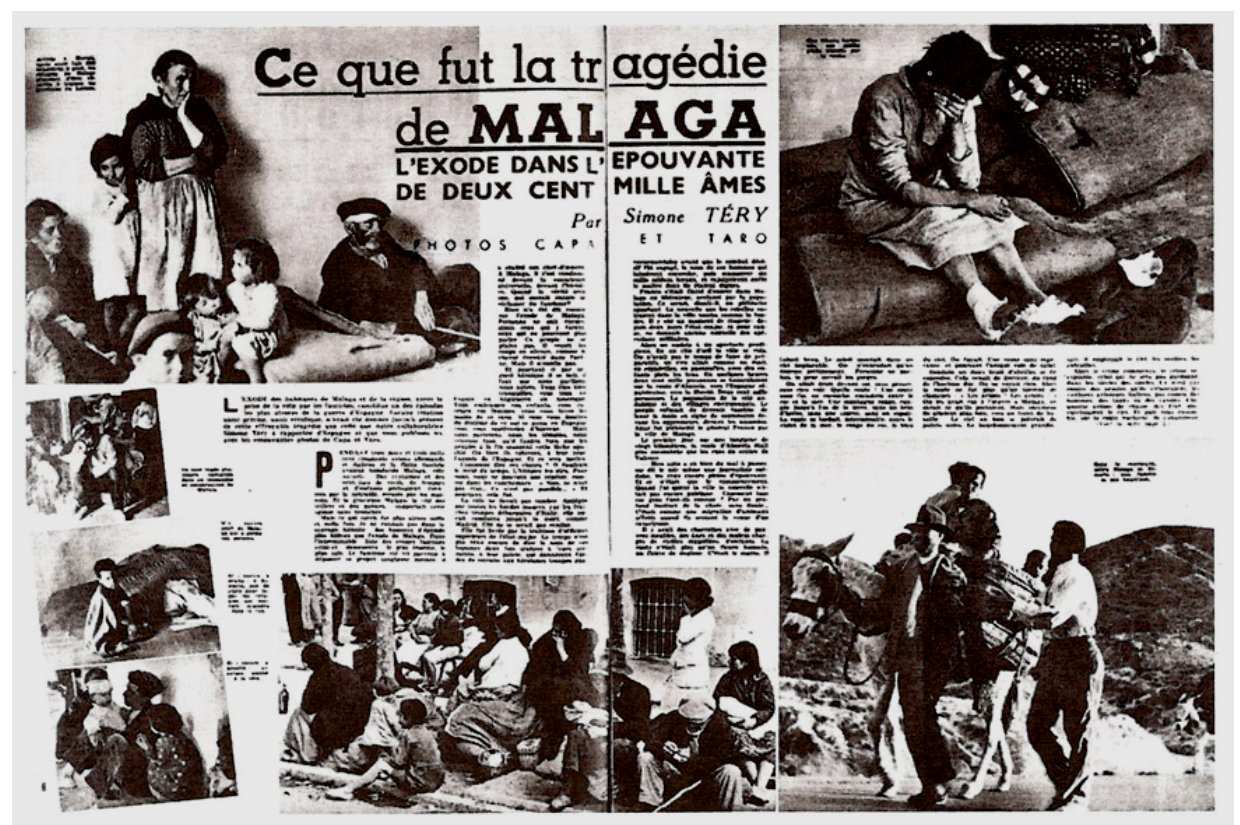

Figura 6. Regards, 18 de marzo de 1937. El reportaje aparece firmado con el sello comunitario "Photos Capa et Taro".

Precisamente el uso masivo de las fotografías en los medios de información escrita explica la gran relevancia que tuvo esta guerra a escala internacional. El año que comienza la guerra española nace en Norteamérica el nuevo formato de Life ${ }^{5}$, una revista especialmente interesada en el suceso español que se convirtió en "la más importante de su género en el mundo" (Freund, 2006: 123) -sólo de su primer número llegó a vender 466.000 ejemplares y

\footnotetext{
5 La revista estadounidense Life fue fundada en 1883 pero tuvo diversas etapas de desarrollo. En 1936 Henry Luce, fundador de Time, compró sus derechos y la redefinió completamente, poniendo gran énfasis en el fotoperiodismo. El formato de Life en 1936 condensaba el texto dentro de 40 páginas dedicadas fundamentalmente a las imágenes.
} 
más de 1 millón por semana cuatro meses después (Gautrand, 2004: 11). Junto a la americana Life, también cabe subrayar la importancia de otras cabeceras europeas como las alemanas Berlin Illustrierte Zeitung, Müncher Illustrierte Press, Die Illustrierte Zeitung y AIZ; la suiza Zürcher Illustrier; las francesas Vu y Regards; la soviética SSSR na Stroike; y la inglesa Picture Post, casi todas influenciadas por el estilo alemán. A rasgos generales, los medios de prensa que nacieron en el contexto europeo y americano de este periodo fueron posicionándose hacia la crítica y el análisis político desde posiciones antagónicas. Por un lado, y más profusas, las inclinadas hacia la crítica social y la defensa de los ideales izquierdistas. Por otro, las entregadas a la difusión de las ideas fascistas. Y así, dada la razón del conflicto, unido a los avances tecnológicos y a los intereses de la prensa, España se tornó en blanco de pruebas del fotoperiodismo y, en consecuencia, en objeto de interés de un público que por primera vez iba a poder conocer cualquier aspecto de una guerra.

\subsection{La mirada}

El fotoperiodismo cobra definitivamente su impulso gracias a los avances técnicos que experimenta la fotografía en la captura y difusión de imágenes durante la década de 1930. Ahora bien, como indica Gisèle Freund. "la imagen que registra la cámara sigue dependiendo del hombre" (Freund, 2008: 7). En esta idea sencilla pero nuclear insiste la fotógrafa y socióloga: "Una fotografía no puede ir más allá de la intención del que la ha hecho (...) El conocimiento técnico es poca cosa; ante todo, hay que aprender a ver" (Freund, 2008: 74). Y en la misma línea avanza el profesor Horacio Fernández al señalar hacia la mirada como el elemento fotográfico clave:

Las variantes de la fotografía no tienen su explicación en la nacionalidad de los fotógrafos, sino en sus diferentes miradas, que, ellas sí, determinan las fotografías tomadas. Por sí misma la mirada es un medio (...) que puede estar más o menos educada en función del entrenamiento al que haya sido sometido el ojo (en VV. AA, 1999, p. 34). 
Cabe tener presente que toda fotografía es, en definitiva, luz, objeto y encuadre, y este principio no es ajeno para el fotoperiodismo. Como sucede en toda actividad fotográfica, la práctica del fotógrafo de prensa se centra en la observación y el enmarcamiento.

Asimismo, la abertura del diafragma y la selección de velocidad de obturación, en función de las condiciones lumínicas $\mathrm{y}$ sensibilidad de la película, le permiten crear diferentes profundidades de campo que dan nitidez o borrosidad a los objetos que enmarca. Por tanto, también en el caso de la fotografía de prensa, el ojo, como medio, interpreta una realidad que reconstruye $\mathrm{y}$ ofrece

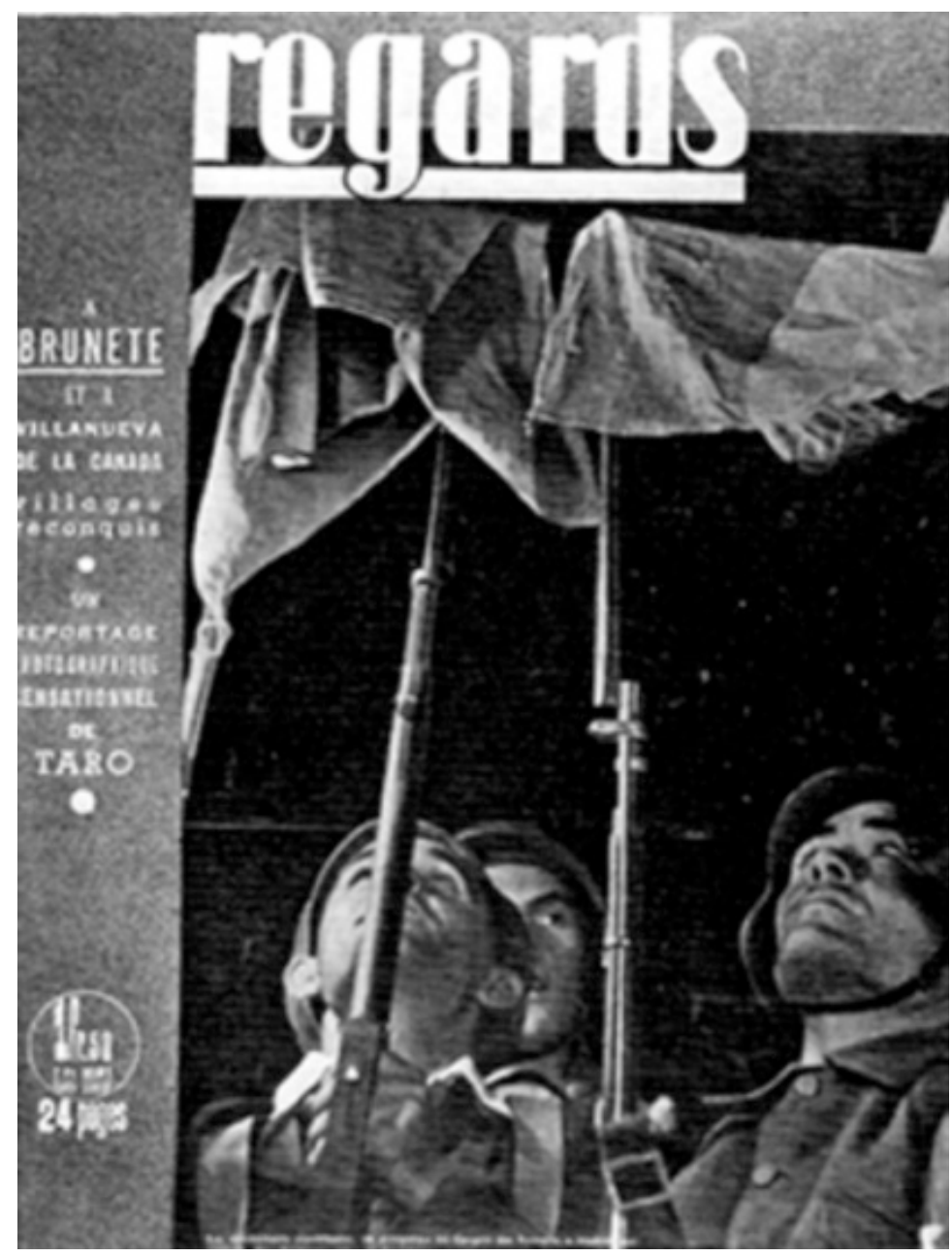

F7. Portada de la revista Regards con fotografía y firma de Gerda Taro publicados cuatro días antes de la muerte de la fotoperiodista.

siempre fragmentada.

Pero, a diferencia de la palabra escrita, la fotografía posee una capacidad inmediata para la descripción a la vez que es expresión de comprensión universal. Esta facultad promueve su gran valor sobre los demás lenguajes, y ante las circunstancias que han hecho posible su uso masivo en los medios de comunicación escrita, la fotografía será una herramienta clave tanto para la función informativa y propagandística de la prensa como para su vertiente empresarial. Luego, el definitivo uso de la imagen fotográfica en prensa 
devendrá en la eclosión del fotoperiodismo como actividad vinculante a la empresa periodística, y con ello, a la consagración del fotoperiodista de guerra, una figura que cobrará importancia décadas más tarde y que podría definirse como un testigo comprometido con lo que observa.

En definitiva, desde que la técnica permite al fotógrafo registrar lo visto en casi cualquier lugar y circunstancia, la imagen destrona progresivamente a la palabra en el contexto de la página impresa, y de este modo la versión comprometida del mediador gráfico se impondrá como el principal punto de vista que asumirán las masas. Algo que va a derivar en la capacidad de los fotógrafos para incidir en la conciencia de la opinión pública y en la relevancia de esta figura que, en consecuencia, comenzará a reivindicar la autoría de su trabajo mediante la firma de sus reportajes, un asunto de interés secundario hasta el momento de la Guerra Civil Española, pero fundamental a partir de entonces en lo que a la foto en prensa se refiere.

Una vez más, todos los aspectos citados concurren en el caso particularmente destacado en este estudio, en el nos disponemos a profundizar una vez hayamos definido la metodología empleada para llevarlo a cabo.

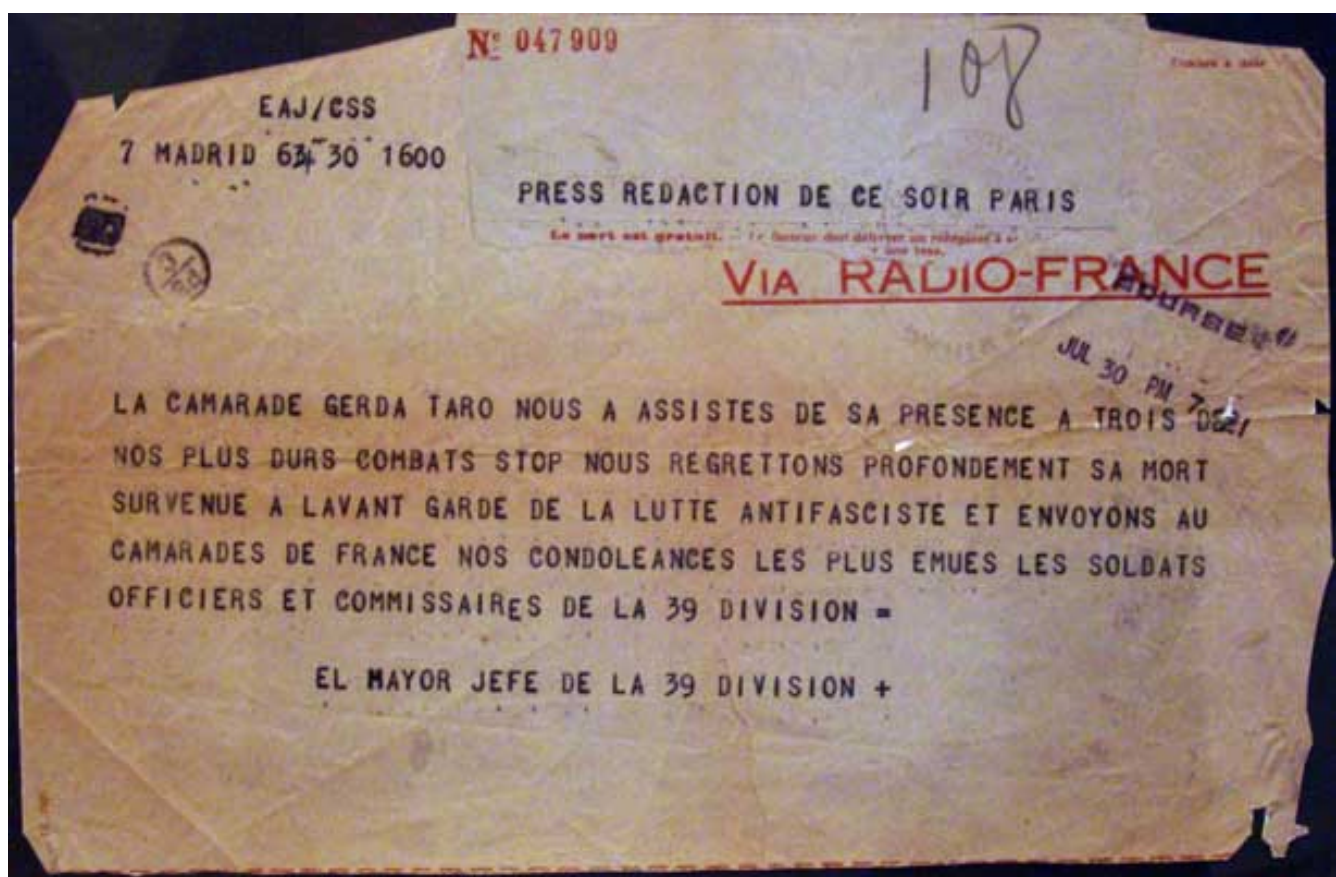

Figura 8. Parte de defunción de Gerda Taro emitido por el ejército republicano español al periódico Ce Soir. 


\section{Metodología}

Esta investigación se nutre del conjunto de series fotográficas realizadas por Gerda Taro en España. La muestra examinada alcanza los 716 documentos y abarca desde sus primeras fotografías realizadas a las milicianas en Barcelona el 5 de agosto de 1936 hasta sus últimas imágenes de la batalla de Brunete, donde la fotoperiodista murió en calidad de corresponsal gráfica de Ce Soir el 25 de julio de 1937.

La metodología propuesta combina la investigación histórica con el análisis semiótico. Por un lado, la observación documental permitirá describir las principales características y usos del objeto de estudio. Por otro, mediante un análisis cualitativo se profundizará en dichas características y usos con tal de dar respuesta a los objetivos señalados inicialmente.

El presente artículo utiliza, por tanto, la técnica del estudio de casos. Esta metodología, al constituir una técnica cualitativa que se basa en el estudio de casos concretos con finalidad de obtener datos que permitan generalizaciones analíticas (Yin, 1994; Simons, 2011), constituye el mecanismo idóneo para aproximarnos a la comprensión de nuestro objeto de estudio, así como para explorar sus características, su funcionamiento y evaluar sus consecuencias (Merriam, 1988). En definitiva, el estudio de casos nos permitirá describir, profundizar y obtener conclusiones regulares en torno a las fotografías de Gerda Taro y el marco que las circunscribe.

\subsection{Fuentes gráficas originales}

Es condición sine qua non de todo estudio que se preste al análisis fotográfico trabajar con originales, y este ha sido el caso ${ }^{6}$. Pero el trabajo fotográfico de Gerda Taro se encuentra íntegramente disuelto entre los fondos fotográficos Robert Capa, que a su vez está diseminado en diferentes centros y archivos fotográficos ubicados en distintas ciudades de América y Europa. Por tanto, en primer lugar se ha realizado un trabajo de campo para

${ }^{6}$ Concretamente, el estudio de la obra de Gerda Taro no permite proceder de otro modo. Dadas las condiciones de realización y conservación de sus fotografías, resulta imposible obtener resultados definitivos si el análisis de la obra no se lleva a cabo sobre originales. 
localizar, examinar e identificar el máximo volumen de obra original de la fotógrafa en diferentes soportes7. Estos documentos, que abarcan todos los temas de su producción, son los siguientes:

- 300 negativos en $35 \mathrm{~mm}$ inéditos procedentes de la maleta mexicana ${ }^{8}$, con tema del sitio de Madrid, el frente del Jarama, el Segundo Congreso Internacional de Escritores Antifascistas inaugurado en Valencia, los intelectuales en La Alianza, los bombardeos en Madrid y Valencia, el entierro del general Lukács en Valencia y los combates en La Granjuela y Brunete. Este material se encuentra actualmente en el International Center of Photography (ICP) de Nueva York.

- 120 negativos en $35 \mathrm{~mm}$ y 7 copias originales -de época y de autorrelativas a los bombardeos de Madrid y Valencia durante 1937. Material hallado en el Archivo Histórico del Partido Comunista Español (PCE) de Madrid.

- 87 ampliaciones procedentes del ICP - copias de época y copias modernas obtenidas a partir de negativo original -y datadas entre agosto de 1936 y julio de 1937.

- 202 copias por contacto en $24 \times 36 \mathrm{~mm}$ ordenadas en varias libretas ubicadas en los Archivos Nacionales de París (ANP) ${ }^{9}$ datadas entre agosto de 1936 y julio de 1937.

\footnotetext{
7 En esta investigación han participado algunas piezas claves, como el investigador Ernesto Viñas, el escritor y periodista Juan Villoro, la cineasta Trisha Ziff, e Isabelle Neuenschwander, directora de los Archivos Nacionales de París. Gracias al primero se ha podido contextualizar la serie de Brunete hallada en México y localizar material inédito en el Archivo del Partido Comunista Español. Mediante Villoro conocimos de primera mano la historia de la obra redescubierta en México, y a través de Neuenschwander accedimos al conjunto de obra de París. Finalmente, Kristen Lubben, conservadora del Centro Internacional de Fotografía de Nueva York, y Trisha Ziff, directora del documental $L a$ maleta mexicana, facilitaron todo acceso a las fotografías de Gerda redescubiertas en México, lo que ha dado lugar a importantes y decisivas conclusiones al tratarse de un conjunto de obra del todo inexplorada.

${ }^{8}$ La maleta mexicana es como se ha dado a llamar el conjunto de tres cajas de cartón en las que permanecieron guardados en México durante décadas los más de 4.000 negativos de Capa, Taro y "Chim" sobre la Guerra Civil Española.

9 Los Archivos Nacionales de París albergan ocho libretas de trabajo que el inventario atribuye a Robert Capa con aproximadamente 2.500 fotografías por contacto sobre el tema de la guerra española [código de referencia del documento: F7/14 740]. Se trata de fotografías reveladas pero sin ampliar en formato $24 \times 36$ pertenecientes a Capa, Taro y "Chim". Nuestro análisis del material determina que gran parte de este conjunto de obra son copias por contacto de los negativos redescubiertos en México.
} 


\subsection{Ordenación taxonómica y análisis semiótico: una propuesta metodológica para el estudio integral de una obra fotográfica específica}

Para realizar el estudio de la obra se ha empleado una fórmula que combina dos procedimientos. En primer lugar, se ha elaborado una taxonomía que ha determinado los casos de estudio más significativos. En segundo lugar, se ha aplicado a cada caso la metodología de análisis fotográfico desarrollado por el catedrático Javier Marzal y el grupo de investigación ITACA-UJI (Marzal, 2007: 173-218). De este modo, podremos resolver cuestiones relacionadas con las variables técnicas, temáticas, compositivas y comunicativas de las imágenes, todas imprescindibles para establecer deducciones en torno al estilo y significación de las fotografías, tanto en sus diversas etapas de producción como en relación con el uso presente (museos) y pasado (prensa) de estas fotografías históricas.

La línea temática de la fotografía de Gerda Taro está claramente comprometida con la cuestión humana, por ello se ha realizado una ordenación taxonómica de tipos humanos que clasifica la obra según los tipos más insistidos en su conjunto, resolviéndose finalmente 10 prototipos diferenciados, cada uno concerniente a una de las cuatro opciones derivadas de la misma categoría temática: el ser humano con identidad antifascista en la circunstancia de la guerra de España. Esta ordenación parte de cuatro clasificaciones fundamentales: el hombre, la mujer, el niño y los restos humanos, que a su vez han resuelto un total de 10 arquetipos diferenciados: el soldado, el miliciano, el campesino y el fotógrafo (el hombre); la miliciana, la intelectual y la madre, (la mujer); los huérfanos (el niño) y cadáveres y ruinas (los restos humanos). Luego, nuestra ordenación de la obra no se rige por criterios cronológicos sino temáticos, lo que ha facilitado profundizar en pocos casos para llegar a niveles connotativos que permitan entender el significado del conjunto de una forma más profunda. Por tanto, aquí es donde se plantea la mayor innovación en la aplicación del método de 
análisis citado $^{10}$, pues por primera vez se adapta al estudio de una obra fotográfica específica y completa, lo que permitirá alcanzar resultados precisos sobre la misma y con relación al contexto fotográfico que la enmarca.

Tabla 1: Indicadores del tema fotográfico: tipos humanos prevalecientes en las fotografías de Gerda Taro ordenados según el nivel de interés de la autora por cada caso

\begin{tabular}{|c|c|c|c|}
\hline EL HOMBRE & LA MUJER & EL NIÑO & $\begin{array}{c}\text { LOS RESTOS } \\
\text { HUMANOS }\end{array}$ \\
\hline El soldado & La miliciana & Huérfanos & Cadáveres \\
\hline El miliciano & La intelectual & & Ruinas \\
\hline El Campesino & La Madre & & \\
\hline El fotógrafo & & & Fuente: elaboración propia
\end{tabular}

En definitiva, la catalogación de la obra por temas ha establecido los principales intereses fotográficos de su autora, lo que ha determinado la elección de las 10 fotografías posteriormente analizadas en profundidad, que son las siguientes:

1. Soldados republicanos (Republican soldiers, 1937). Publicada en el periódico Ce Soir el 16 de julio de 1937, p. 8. Analizada copia de época (ICP) y copia por contacto (cuaderno $\mathrm{n}^{\mathrm{o}} 1, \mathrm{ANP}$ ).

2. $\quad$ Tres soldados republicanos (Three republican soldiers, 1936). Analizada copia moderna procedente de negativo original (ICP).

3. $\quad$ Agricultores cargando un carro (Agricultural workers loading cart, 1936). Analizada copia moderna obtenida de negativo original (ICP).

4. Robert Capa (Robert Capa, 1937) publicada en el $\mathrm{n}^{0} 10$ de Picture Post el 3 de diciembre de 1938, p.23. Analizada copia de época (ICP).

5. Miliciana republicana entrenando en la playa (Republican militiawomen training on the beach, outside Barcelona, 1936). Publicada en la revista Vu el 29 de agosto de 1936, p.42. Analizada copia de época (ICP).

${ }^{10}$ La metodología empleada para el análisis fotográfico también se puede encontrar en la siguiente URL [http://www.analisisfotografia.uji.es/] 
6. Anna Seghers (Anna Seghers, 1937): publicada en el diario Ce Soir el 11 de julio de 1937, última página. Analizada copia de época (PCE) y copia por contacto (cuaderno $\mathrm{n}^{\mathrm{o}} 1$, ANP).

7. Refugiados de Málaga en Almería (Refugees from Málaga in Almería, 1937). Publicada en la revista Regards el 18 de marzo de 1937, p.6, y portada del semanal Volks-Illustrierte el 30 de junio de 1937. Analizada copia de época (ICP) y copias por contacto paralelas (cuaderno $\left.\mathrm{n}^{\mathrm{o}} 3, \mathrm{ANP}\right)^{11}$.

8. Huérfanos de guerra en círculo (War Orphans in circle, 1937). Analizada copia moderna obtenida de negativo original (ICP).

9. Víctimas de los bombardeos en la morgue (Air raid victims in the morgue, 1937): publicada en Regards el 10 de junio de 1937, portada. Analizado negativo inédito digitalizado procedente de La maleta mexicana (ICP, red box, $\mathrm{n}^{0}$ 073) y copia por contacto (cuaderno $\mathrm{n}^{\circ} 4$, ANP).

10. $S / T(\mathrm{~S} / T)$-efectos de los bombardeos, 1937- publicada el 28 de julio de 2008 en El Periódico. Analizado negativo inédito digitalizado redescubierto en México (ICP, $\tan$ box, $\left.\mathrm{n}^{0} 498\right)$.

A continuación presentaremos los principales resultados de los análisis acompañados de fragmentos del método desarrollado sobre dos casos significativos: una fotografía de Gerda Taro realizada con la cámara de formato medio Rolleiflex y otra realizada con la cámara Leica de pequeño formato ${ }^{12}$.

\section{Análisis y valoración de los resultados}

La Guerra Civil Española marcó un punto de inflexión en la historia del fotoperiodismo gracias, en buena medida, a los avances técnicos logrados hasta entonces en la captura y difusión de imágenes fotográficas. Si bien la

${ }^{11}$ La libreta de trabajo $\mathrm{n}^{\circ} 3$ (ANP) incluye sobre el mismo tema cuatro contactos en $35 \mathrm{~mm} \mathrm{y}$ uno en formato cuadrado. Éste último es el único hallado en formato $6 \times 6$ entre los más de 2.500 contactos examinados en este archivo.

12 Para el desarrollo de este trabajo se han realizado ensayos prácticos con cámaras homólogas a las utilizadas por la fotoperiodista, estas son: una Rolleicord con objetivo Xenar $75 \mathrm{~mm} \mathrm{f} / 3,5$, y una Leica IIIa con objetivo Elmar 50mm f/3,5. Los resultados de estas prácticas realizados en los mismos lugares que aparecen fotografiados en las imágenes analizadas han resultado determinantes para la catalogación e identificación de la obra de Gerda Taro (véase Figura. 11). 
primera Gran Guerra produjo, a consecuencia del uso de las cámaras del momento, imágenes estáticas, recreadas en la composición y en el retrato enaltecido del referente, en la Segunda Guerra Mundial las posibilidades que ofrece la técnica ya han liberado definitivamente la práctica del fotógrafo, quien en casi cualquier momento y lugar puede registrar lo visto mediante su capacidad para percibir, presenciar y capturar los hechos más significativos.

En este sentido, el trabajo de Gerda Taro resulta idóneo para ilustrar el periodo de transición fotográfica que supuso el momento fotográfico de la Guerra Civil, ya que el estilo de Gerda también es cambiante según trabaje con el formato medio inicial y el uso posterior del formato pequeño. La visión estética, poética y amoldada a las exigencias del realismo socialista que habitualmente ofrece la autora con el uso inicial de la cámara Rolleiflex cede el paso a un documentalismo ágil y espontáneo que promueve el uso de la cámara Leica. Como en los modelos de fotografía desarrollados durante la Primera y la Segunda Guerra Mundial, respectivamente, en los rasgos generales que definen el estilo de esta fotógrafa también es concluyente la cámara que utiliza en cada momento, pues cada una de ellas facilita una modalidad a la visión. En síntesis, el formato medio o 6x6 es promotor de una visión lenta pero precisa, mientras que el formato pequeño o $35 \mathrm{~mm}$ facilita un modo de ver más rápido e intuitivo. Todo ello puede traducirse en dos maneras diferentes de abordar la práctica fotográfica, que a su vez resuelven resultados también distintos. En el caso concreto de Gerda Taro, y según la línea ordenada de su producción, con el uso de la Rolleiflex la fotógrafa desarrolla un estilo estático y preciso que destaca por la originalidad de los encuadres y el posado de los referentes. Con el uso de la Leica, sin embargo, la autora ofrece un testimonio más espontáneo que deja en segundo plano el interés por la nitidez y la composición de la imagen. Aunque cada serie fotográfica es coherente en sí y en el conjunto de la obra, éstas muestran rasgos diferenciados que son explícitamente apreciables en la comparativa entre las primeras series realizadas con la cámara Rolleiflex en Cataluña y Aragón, y las últimas de Valencia y Brunete realizadas con la cámara Leica. 
Por otro lado, la ordenación taxonómica de la obra revela que el tipo humano más insistido en la fotografía de Taro es el hombre, esencialmente bajo el aspecto del soldado, el miliciano y el campesino, tres arquetipos a través de los cuales la fotógrafa ofrece un testimonio de la nueva forma de organización que ha implantado el comunismo libertario, principal opositor del fascismo internacional.

La figura de la mujer aparece fundamentalmente retratada bajo la apariencia de la miliciana y la intelectual, lo que revela que el tipo de mujer que principalmente ocupa la fotografía de la autora no refleja la verdadera realidad femenina española durante 1936 y 1937. Aquella realidad mantenía la actitud convencionalista del arquetipo tradicional femenino y rural; sin embargo, los modelos de mujer que prevalecen en las fotografías de Taro son los que actúan en igualdad de condición que sus homólogos varones, es decir, los que desafían los poderes y/o divisiones de espacios y roles, y estos son, en definitiva, ejemplos de una minoría en la realidad femenina del escenario español de la época. Luego, en este caso cabría subrayar la significación del tipo humano de la mujer con relación a las implicaciones que plantea su representación en esta obra dado que, muy a menudo, la identidad de grupos se consolida a partir de las imágenes que se consumen en la sociedad, y el tipo de mujer que promueve su fotografía no es ni mucho menos compasiva o generadora de compasión, sino más bien aquella que promueve la igualdad de género, por lo que se la podría relacionar con un adelantado reforzamiento de ciertos códigos de conducta imperantes en el siglo XXI.

La figura del niño, incluso bajo la apariencia del huérfano, es principalmente representada como elemento evocador a la causa leal. Por encima de cualquier convencionalismo -el niño mirado fotográficamente como víctima-, la obra de Taro prioriza sobre el tema de la infancia feliz, y todo con una singularidad muy significativa: la gran mayoría de niños que protagonizan sus fotografías se vinculan entre sí por el uso del típico birrete de la milicia, lo que principalmente convierte a este tipo humano en objeto de referencia propagandística. 
Por último, hombres, mujeres y niños sin vida aparecen representados en igualdad de condición en el apartado de los restos humanos, donde el principal aspecto a destacar es la identidad antifascista de las víctimas.

Tabla 2: Principales resultados del análisis de la fotografía Tres soldados republicanos, realizada por Gerda Taro con la cámara Rolleiflex ${ }^{13}$

\begin{tabular}{|c|c|c|}
\hline Miliciar & & \\
\hline & $\begin{array}{c}\text { Título } \\
\text { original }\end{array}$ & Three Republican soldiers \\
\hline & Lugar & Espejo, Córdoba \\
\hline & Fecha & Principios de septiembre de 1936 \\
\hline & Procedencia & $\begin{array}{l}\text { Internacional Center of Photography de } \\
\text { Nueva York }\end{array}$ \\
\hline & Consulta & $\begin{array}{l}\text { Copia moderna en gelatina de plata de } \\
\text { negativo original } \\
\text { Museo Nacional d'Art de Catalunya, } \\
\text { Barcelona / Art Barbican Gallery, Londres }\end{array}$ \\
\hline & Géneros & 4. $\quad$ Fotografía de guerra \\
\hline & Cámara & $\begin{array}{l}\text { Rolleiflex Old Satndard/ Carl Zeiss Tessar } 75 \\
\text { mm, f/3,5 }\end{array}$ \\
\hline $\begin{array}{l}\text { Esta fotografía forma parte de la serie de } \\
\text { Capa realizó la fotografía Muerte de un } \\
1936 \text { convertiría a su autor en un refer } \\
\text { aparece también fotografiado el protagor } \\
\text { que Taro y Capa trabajaban codo a codo } \\
\text { y la jerarquización atípica del espacio. A } \\
\text { asalta con elementos desconcertantes, cc } \\
\text { que los dos sujetos del fondo interactúa } \\
\text { uno reposa plácidamente, el otro le ap } \\
\text { enunciativas inducen a razonar la toma } \\
\text { enunciado por los protagonistas de la } \\
\text { actividad en el frente. Pero, tras realiz } \\
\text { fotógrafa se encontraba a un metro apr } \\
\text { enemigo. Por tanto, todo apunta que el }\end{array}$ & $\begin{array}{l}\text { ata imágenes } \\
\text { ano, imagen } \\
\text { undial del fo } \\
\text { la célebre to } \\
\text { Tres soldad } \\
\text { lo, la interacc } \\
\text { actitud de los } \\
\text { sí. No encor } \\
\text { la cabeza co } \\
\text { tir de una re } \\
\text { fía y es el } \mathrm{m} \\
\text { pruebas opor } \\
\text { lo del primer } \\
\text { le campo esta }\end{array}$ & $\begin{array}{l}\text { de han documentado la jornada donde Robert } \\
\text { ya publicación en } V u \text { el } 23 \text { de septiembre de } \\
\text { periodismo. En esta imagen de Gerda Taro } \\
\text { (primero por la izquierda), lo que demuestra } \\
\text { republicanos destaca por el desorden icónico } \\
\text { n de los sujetos provoca conflicto. La imagen } \\
\text { ersonajes. Resulta incoherente el modo en el } \\
\text { camos explicación a sus poses, pues mientras } \\
\text { su arma. Por tanto, las pruebas históricas y } \\
\text { idad reconstruida. El fuera de campo queda } \\
\text { ximo elemento de tensión dado que sugiere } \\
\text { anas, según los ajustes técnicos imitados, la } \\
\text { lemento y ofreciendo la espalda al supuesto } \\
\text { anicamente ocupado por los fotógrafos en un }\end{array}$ \\
\hline
\end{tabular}

Tabla 3: Principales resultados del análisis de la fotografía Anna Seghers, realizada por Gerda Taro con la cámara Leica

\begin{tabular}{|c|c|c|}
\hline \multicolumn{3}{|l|}{ La Intelectual } \\
\hline & $\begin{array}{l}\text { Título } \\
\text { original }\end{array}$ & Anna Seghers \\
\hline & Lugar & $\begin{array}{l}\text { Hemiciclo del Ayuntamiento de } \\
\text { Valencia }\end{array}$ \\
\hline & Fecha & 4 de julio de 1937 \\
\hline & Procedencia & Archivo Histórico del Partido \\
\hline
\end{tabular}

${ }_{13} \mathrm{El}$ análisis de esta fotografía se encuentra íntegramente desarrollado en la investigación Documentalismo técnico en la Guerra Civil Española. Inicios del fotoperiodismo moderno en relación a la obra de Gerda Taro (Arroyo, 2010: 347-384), del mismo modo que el siguiente análisis de la fotografía que ilustra la Tabla 3 (493-512). 


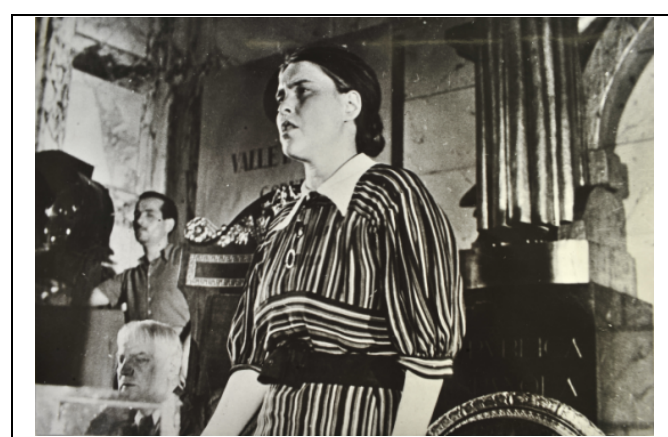

\begin{tabular}{|c|l|}
\hline & Comunista Español \\
\hline Consulta & $\begin{array}{l}\text { Copia de época procedente del Archivo } \\
\text { Histórico del Partido Comunista } \\
\text { Español/ copia por contacto procedente } \\
\text { del cuaderno } \mathrm{n}^{0} \text { 1, Archivos Nacionales } \\
\text { de París }\end{array}$ \\
\hline Géneros & $5 \cdot \quad$ Fotografía informativa \\
\hline Cámara & $\begin{array}{l}\text { Leica IIIa/ Elmar f/3,5-50 mm o un } \\
\text { Summar f/2 -50 mm }\end{array}$ \\
\hline Publicación & $\begin{array}{l}\text { Publicada en Ce Soir el 11 de julio de } \\
1937\end{array}$ \\
\hline
\end{tabular}

La fotografía muestra a Anna Seghers durante su intervención en el II Congreso de Escritores Antifascistas para la Defensa de la Cultura en Valencia. El rostro de Seghers desafía al público con la autodeterminación que percibimos a partir de la elevación del mentón y la mirada fruncida, en lontananza. Aquello que justifica la presencia de Seghers y Taro en España durante el tiempo de la guerra es la firme intención antifascista de ambas. Esta es la principal circunstancia que las vincula, pero además las dos son mujeres jóvenes, alemanas y de origen judío que han viajado hasta España para vivir y contar en primera persona la experiencia de una guerra ajena. Cada una participa de esta lucha como mediadora, con la imagen o la palabra, y en igualdad de condiciones que sus homólogos. Cada una también ha optado por el uso de un pseudónimo que oculta sus identidades para firmar su trabajo. Luego, cabe subrayar los puntos de contacto que vinculan a la fotógrafa con el referente de esta imagen. Fotografía de autor sellada con el tampón "Photo Taro".

Fuente: elaboración propia

Fijándonos en lo que encuadra y, por tanto, excluye la fotógrafa, ha podido resolverse que las imágenes de Taro son, ante todo, testigo y muestra de dignidad y valor con identidad antifascista, creadas como herramientas para afectar a la esfera social y política a través de la esfera mediática. En este motivo insiste, además, el componente estético de su trabajo, que ensalza a las figuras según las posibilidades narrativas que ofrece el lenguaje de la imagen técnica durante los años 30. Este modo de afrontar la práctica fotográfica se ha resuelto como consecuencia del marco donde se forma la mirada de la fotógrafa, un contexto de cultura visual promovido por el cine y las vanguardias europeas que pondrán de relieve esta influencia en una práctica absolutamente novedosa para el fotoperiodismo de guerra: contrapicados con los que la autora exalta a los sujetos fotografiados, y que aplicados a los escenarios obreros o militares emparentan sus fotografías con los modos de expresión de la vanguardia soviética; también el uso de velocidades bajas para obtener un efecto borroso que aporta dinamismo y tensión a la imagen. Todo bajo la intención persuasiva de lograr difundir una determinada visión, principalmente heroica, de los hechos.

Sin embargo, casi se ha convertido en lugar común destacar del trabajo de Gerda Taro su especial interés fotográfico por determinados tipos humanos 
como las mujeres y los niños, o lo que es lo mismo, los casos de naturaleza más vulnerable en el contexto de una guerra. Hacia este sentido apuntan las declaraciones de algunos expertos, como las realizadas por el historiador y responsable del Departamento de Fotografía del Museo Nacional d'Art de Catalunya (MNAC) David Balsells en El Periódico de Catalunya a propósito de la inauguración de la muestra que exhibió por primera vez unidas las fotografías realizadas por Taro y Capa durante la Guerra Civil14. La ordenación de la obra llevada a cabo para este estudio desmiente este indicador, intuyéndose fundamentado en los presupuestos que habitualmente se asocian a los resultados fotográficos de una autora a la que, por su condición de mujer, se le intuye o atribuye casi de manera instantánea una facultad extra de sensibilidad, y en consecuencia una determinada manera de ver, comúnmente denominada femenina ${ }^{15}$. De hecho, de presentar estos rasgos concretos tampoco podrían explicarse los problemas de autoría que han presentado durante más de siete décadas las fotografías de Taro y Capa realizadas en España, ya que los rasgos específicos atribuidos a la mirada de Taro por su condición de mujer hubieran resuelto los problemas de atribución de imágenes que han afectado, entre otras, a la icónica fotografía Muerte de un miliciano.

El periodista australiano Phillip Knightley fue pionero en la cuestión que abrió el mencionado debate en su libro The first casualty, donde no descartaba la atribución de esta imagen a Gerda (Knightley, 2004: 74). Desde entonces, diversos analistas y estudioso de la obra de los fotógrafos han tratado el problema de la autoría, como Irme Schaber, biógrafa de Taro, quien comentaba a propósito de Muerte de un miliciano que "es muy poco probable que Gerda hubiera sacado la fotografía, pero es posible” (en Kershaw, 2003: 75). El documental La sombra del iceberg tampoco descarta

\footnotetext{
${ }^{14}$ Las declaraciones del historiador David Balsells aparecieron publicadas en El Periódico de Catalunya el 23 de julio de 2008 a propósito de la inauguración de la muestra en el MNAC iEsto es la guerra!, Robert Capa en acción y Gerda Taro.

15 De modo anecdótico puede señalarse el protagonismo que alcanzan las figuras femeninas e infantil en la obra de Robert Capa, autor del monográfico Children of war, children of peace (1991), aunque en su lugar su efecto en ningún caso va asociado a otro tipo de mirada que no sea la comprometida.
} 
el planteamiento iniciado por Knightley, mientras que el profesor J. $\mathrm{M}^{\mathrm{a}}$ Susperregui defiende la hipótesis contraria atribuyendo el disparo a Robert Capa con la cámara Rolleiflex (Susperregui, 2009: 83-86). Por último, el historiador Carlos Serrano no ha abordado este problema concreto porque estableció que no podía determinarse con exactitud a quién corresponde cada disparo durante la etapa previa a la independencia profesional de Taro, dado que hasta entonces ambos fotógrafos trabajaban codo a codo, compartían cámaras, reportajes y firma en los mismos diarios y revistas (Serrano, 1987: 8).

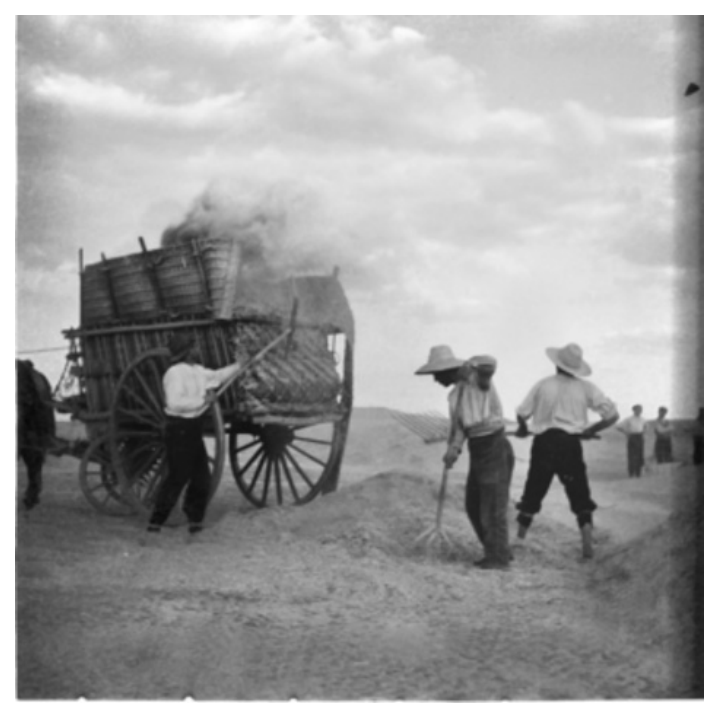

F9. Agricultores cargando un carro Frente de Aragón (muy posiblemente Leciñena, Zaragoza), Agosto de 1936. Fotografía de Gerda Taro (C) ICP.

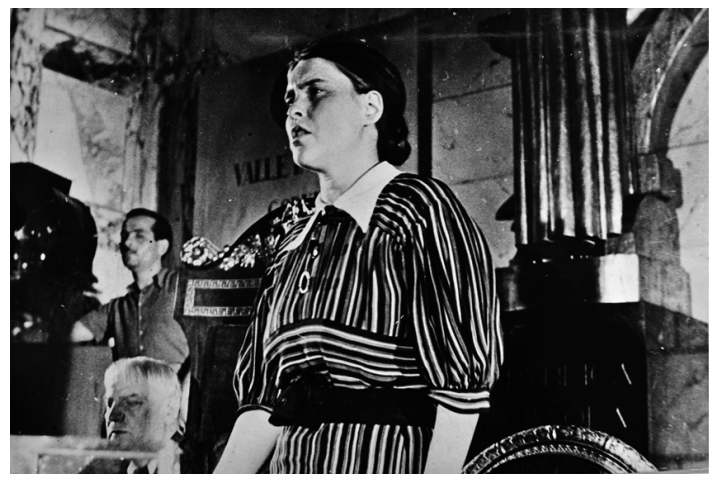

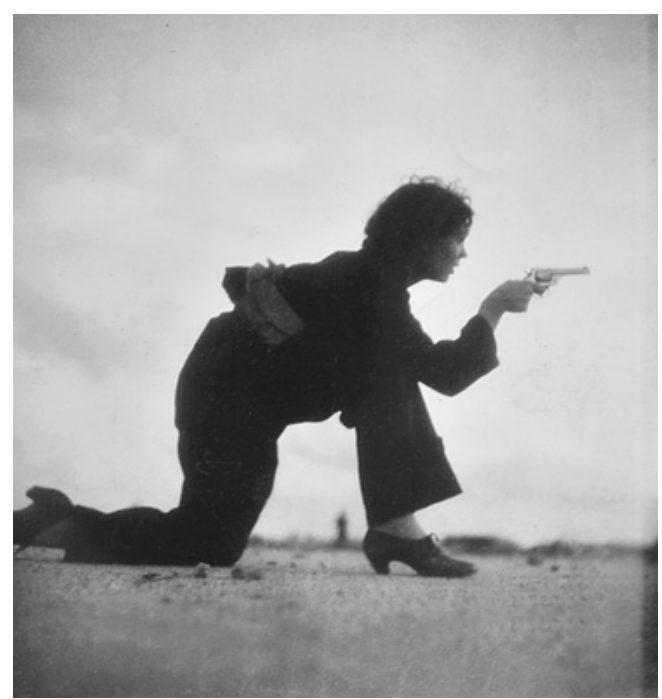

F10. Miliciana republicana entrenando en la playa, afueras de Barcelona, publicada en $V u$ el 29 de agosto de 1936, p.42. Fotografía de Gerda Taro (C) ICP.

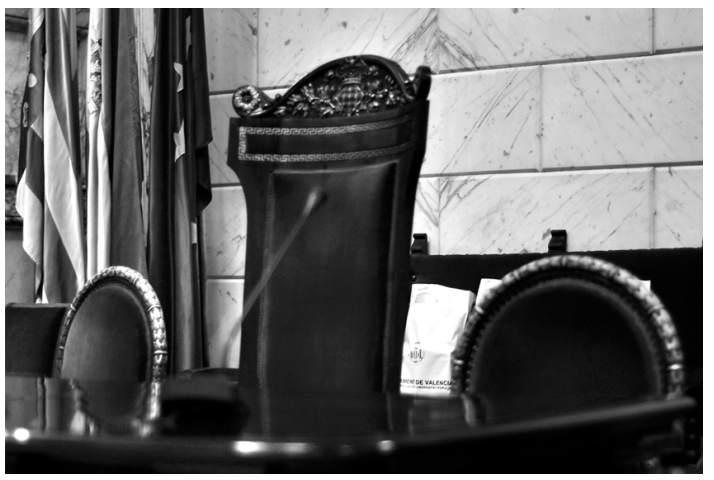

F11 y F12. Anna Seghers en la sala del hemiciclo de Valencia durante el II Congreso de Escritores Antifascistas y publicada en el periódico Ce Soir el 11 de julio de 1937, última página fotografía de Gerda Taro (PCE). La siguiente fotografía, de archivo propio, fue obtenida en la misma sala durante nuestros ensayos. 


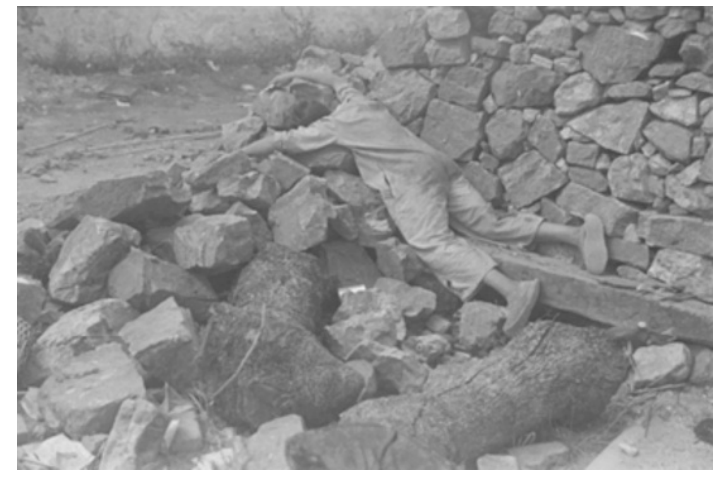

F13. S/T (efectos de los bombardeos en Segovia, 1937). Negativo inédito reaparecido en México (tan box, $\left.\mathrm{n}^{\circ} 498\right)$. Fotografía de Gerda Taro $\mathbb{C}$ ICP.

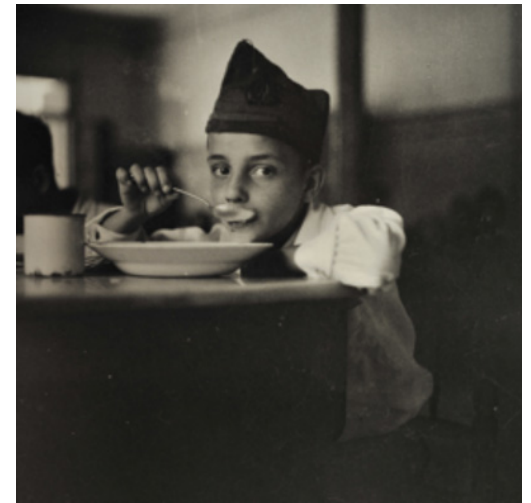

F14. Huérfano de guerra comiendo sopa Madrid, 1937. Fotografía de Gerda Taro (C) ICP.

Gerda Taro comienza firmando sus fotografías en prensa con el sello "Photo Capa" - firma inicial del tándem-, y a la vez que la guerra avanza se consolida el éxito independiente de esta fotoperiodista que personificó, entre otros, el binomio mujer-fotografía de guerra y la máxima futura de Robert Capa: acercarse todo lo posible al tema para lograr las mejores fotografías, aún a riesgo de morir, con tal de ofrecer las imágenes más convincentes e impactantes. Con todo, durante décadas, el nombre de esta autora ha figurado en la Historia de la Fotografía como el de la mujer que acompañó a

Robert Capa durante su etapa más significativa, cuando se convirtió en icono del fotoperiodismo gracias a la publicación del miliciano abatido en el frente de Córdoba. Pero esta fotografía se enmarca dentro de una serie realizada por los dos fotógrafos cuando ambos publicaban $\mathrm{y}$ firmaban en común sus reportajes. La imagen del miliciano, publicada originariamente en la revista $V u$ en septiembre de 1936 y posteriormente en la revista Life el 12 de julio de 1937, fue también portada del libro Death in the making, un homenaje póstumo que Capa realizó a Taro en 1938 y que incluía el

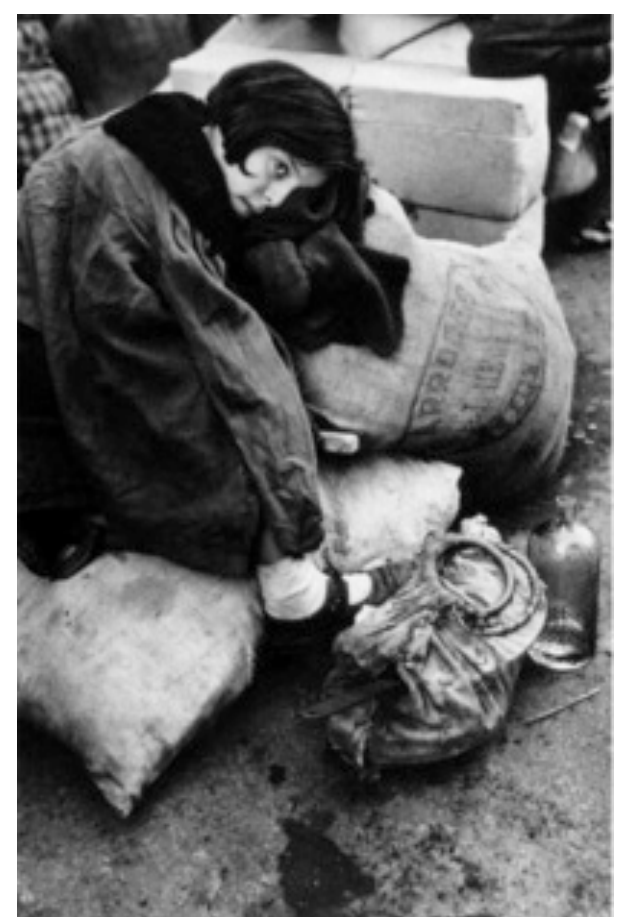

F15. Niña en el centro de refugiados de tránsito de Barcelona, 1939 Fotografía de Robert Capa (C) ICP. 
relato ilustrado de la Guerra Civil con imágenes de ambos pero sin firmar. Al parecer, Capa decidió publicar de este modo las fotografías para priorizar el contenido del mensaje sobre la autoría individual, dado que ninguna de las imágenes aparece identificada por su autor empírico y lo que el libro en definitiva destaca es un testimonio conjunto de la guerra de España. No obstante, esta primera edición del libro-homenaje favoreció el problema de atribución de imágenes que ha afectado sobre todo a la obra de Taro, pues tras la muerte de la fotógrafa nadie reclamó su legado - sus familiares directos fueron exterminados por el nazismo-, y sus fotografías quedaron disueltas en el fondo de imágenes atribuidas a Robert Capa. Sin embargo, el problema se agravó cuando Capa continuó haciendo uso propio de algunas imágenes de su compañera fallecida mediante la ocultación del sello "Photo Taro" con adhesivos de Pix - agencia para la que entonces trabajaba el fotógrafo- o el tachado de la firma original en el reverso de las copias por Credit Robert Capa-Magnum (Schaber, Whelan y Lubben, 2007: 42-47). Finalmente, ni los herederos de Capa ni Richard Whelan, su biógrafo oficial, trataron de esclarecer estos temas tras la muerte del fotógrafo en Vietnam, y sólo más de setenta años después se ha podido arrojar luz sobre algunas de estas cuestiones mediante la posibilidad de estudio y análisis de las fotografías de Taro. Por tanto, aunque durante el periodo inicial del tándem lo importante no fue la singularización de las imágenes sino la expansión del mensaje, lo cierto es que el éxito que reportó a Capa en exclusiva Muerte de un miliciano parece marcar el detonante de la independencia profesional de Taro en su afán por alcanzar un lugar propio en la profesión.

Según Ruth Cerf, amiga de juventud de la fotógrafa, Taro estaba lejos de consentir que su trabajo fuera eclipsado por la súbita fama de su compañero; también consideraba propio el mérito de la icónica imagen, dado que su captura se enmarca en una misma jornada donde se desarrolló un método basado en el trabajo de equipo para lograr imágenes que impresionaran a la opinión pública mediante su publicación en reportajes firmados conjuntamente (en Schaber, 2006: 176). Sin embargo, la firma "Capa" tras la publicación de Muerte de un miliciano fue únicamente vinculante al 
componente varón de la sociedad, con un mérito asociado al valor del hombre que había arriesgado su vida para conseguir imágenes como aquella, aunque la realidad fuera que la secuencia a la que pertenece el soldado cayendo había sido realizada por ambos. Por tanto, con toda probabilidad, esta metodología y el uso de la firma común hubieran supuesto la invisibilidad constante del trabajo de la fotoperiodista, a no ser que, como sucedió, abogara por la independencia profesional y el esfuerzo por obtener en solitario un trabajo de impacto equivalente al hasta entonces logrado junto a su compañero.

Durante su cobertura de la Batalla de Brunete Gerda Taro comenzó a cosechar sus primeros éxitos independientes. El 14 de julio sus imágenes del II Congreso de Escritores aparecieron publicadas en la primera página del periódico Ce Soir y la serie de La Granjuela en la página 10. Ese mismo día, también Ce Soir destacaba su trabajo de Brunete, y el día 18 publicaba una serie de imágenes realizadas junto a Capa durante los últimos meses que compartieron en España. La revista Regards, por su parte, concedía cinco páginas a sus imágenes sobre el Congreso y Brunete, y el 14 de julio publicaba un especial sobre España con algunas de sus fotografías de Segovia y Valencia. Finalmente, tres días antes de morir, Taro firmaba su último reportaje en esta revista, que dedicó espacios destacados a sus imágenes de Brunete. Efectivamente, todo apunta a su consagración como fotoperiodista independiente, aunque no puede afirmarse que hubiera logrado una imagen del impacto que causó Muerte de un miliciano. Luego, también podría explicarse la última etapa de la fotógrafa en su intento por obtener desde la primera línea del frente una imagen de fuerza homóloga a la del famoso miliciano, es decir, una fotografía aislada pero interpretada como imagen global que permitiera percibir el todo de una guerra.

En definitiva, la combinación de temas y estilos en el conjunto de obra de Gerda Taro apunta hacia la intención de la fotógrafa por expresarse a sí misma a través de las referencias humanas especialmente insistidas en sus fotografías, esto es, la expresión de los rasgos y valores que definen su identidad en un amplio abanico de aspectos, de los que destaca el ideológico 
bajo cualquier forma humana que se preste. Precisamente por ello, su obra destaca una serie de arquetipos que contrastan con los más insistidos en las fotografías de Robert Capa, que en su caso son los que simbolizan el desconsuelo, el temor, la esperanza y, en menor grado, la revolución. El culto al héroe anónimo es otro de los principales intereses de esta fotógrafa que ve en España, a partir de sujetos representativos de las clases rurales trabajadoras, intelectuales y las mujeres ideológicamente activas, a los nuevos ídolos de la sociedad. En este caso predominan las fotografías reposadas y obtenidas con la cámara Rolleiflex. Sin embargo, a raíz del uso posterior de la cámara Leica, su actividad fotográfica se revela mucho más arriesgada e intensa. Según se adivina la ubicación de la fotógrafa por el punto de sus tomas es evidente que emancipada de Capa y con la cámara Leica asume riesgos cada vez mayores, lo que únicamente ha podido explicarse según un doble afán: por un lado, el de ofrecer el relato del testigo en primera línea del frente, y por otro, el de lograr las verdaderas imágenes impactantes que la prensa prioriza para su publicación. Los resultados de los análisis también muestran cómo en torno a este último aspecto se rigen casi todas las series fotográficas realizadas por la autora durante su periodo de independencia profesional, y uno de los ejemplos gráficos que mejor ilustran este hecho son sus imágenes de los cadáveres en la morgue del Hospital General de Valencia, analizados para el apartado de los restos humanos. Estas fotografías, realizadas mediante el uso de picados tendrán una tremenda capacidad de impresionar y conmocionar a la opinión pública, por primera vez espectadora de

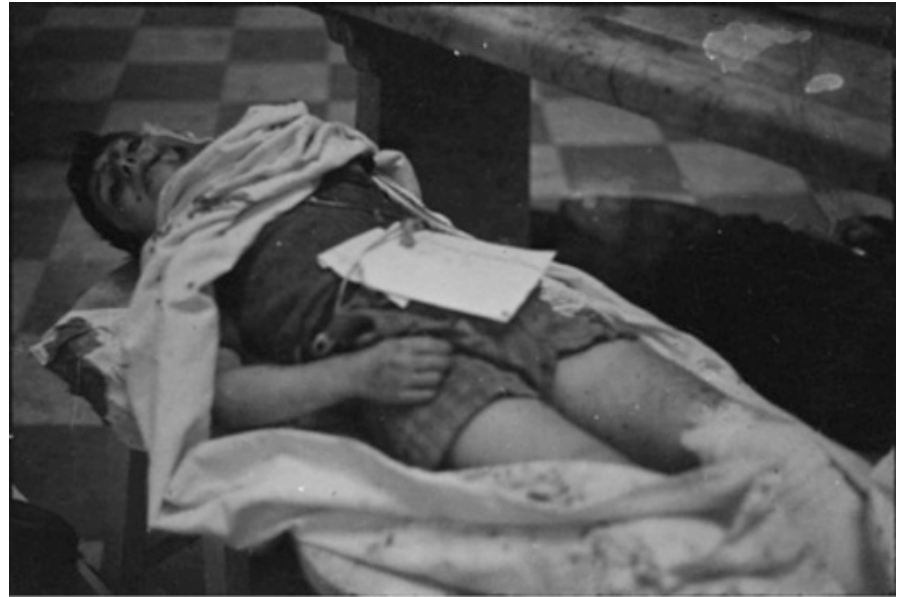

F16. Víctima de un bombardeo en el depósito de cadáveres, Valencia, mediados de mayo de 1937. Fotografía de Gerda Taro (C) ICP 
calamidades ajenas, una cuestión que se propone como experiencia intrínseca de la modernidad.

\section{Conclusiones}

Gerda Taro, alemana de origen judío y exiliada en París durante los primeros años 30, comienza su carrera fotoperiodística junto a Robert Capa en España semanas después del inicio del conflicto y en poco más de un año muere en su decisivo momento profesional. En este ínterin, la fotoperiodista definirá su estilo y sello comercial en paralelo al desarrollo de los acontecimientos de la Guerra Civil Española, el tema absoluto de su trabajo fotoperiodístico. Los resultados de este estudio resuelven que la práctica de esta autora y la de los fotógrafos que se relacionaron con ella en la guerra de España contribuyeron a la redefinición del concepto de fotoperiodismo en occidente.

En segundo lugar, cabe destacar que las imágenes de Gerda Taro son, ante todo, testigo y muestra de dignidad y valor con identidad antifascista mediante las cuales las publicaciones periódicas realizaban apelaciones directas a los lectores. Quedaba entonces por esclarecer por qué casi se ha convertido en lugar común indicar que la fotografía de esta autora está especialmente interesada en las mujeres y los niños. Esta es otras de las razones por las que optamos por una ordenación taxonómica que organizara la obra a razón del tema, en este caso a partir los tipos humanos más insistidos o relevantes en su conjunto, para después analizar pormenorizadamente cada caso. Las conclusiones obtenidas del doble método refutan este postulado, intuyéndose fundamentado en los presupuestos que habitualmente se asocian a los resultados prácticos de una fotógrafa a la que, por su condición de mujer, se le intuye y/o atribuye casi de manera instantánea una facultad extra de sensibilidad, y de la que resulta una determinada manera fotográfica de ver, comúnmente denominada femenina. Por ello, uno de los principales objetivos de este estudio ha sido subrayar la importancia de la mirada - pionera y no femenina- desplegada sobre todo como una forma de acción sobre un contexto en conflicto. 
También poner de relieve la influencia que recibe la fotografía moderna de los demás lenguajes expresivos con los que cohabita antes de que fotógrafos como la alemana Gerda Taro trasladaran este nuevo modo de ver al campo de batalla español y crearán con él un modelo de fotoperiodismo hasta entonces sin precedentes. De este modo, hemos podido determinar que las posibles variantes de la mirada fotográfica, por sí misma un medio, no tienen su explicación en el sexo del fotógrafo sino en la elección de su equipo técnico y en la educación y entrenamiento al que ha sido sometido su ojo.

El enfoque de este texto difiere de los escritos tradicionales sobre la cuestión de la fotografía de la Guerra Civil Española, un tema aparentemente superado y que, sin embargo, según este estudio plantea hipótesis nuevas a partir del caso que destaca. En primer lugar, pone de relieve la influencia que reciben las prácticas fotoperiodísticas desarrolladas en la guerra española de los demás lenguajes expresivos con los que cohabita la fotografía moderna. En segundo, vincula el nacimiento de la figura del reportero de guerra moderno, extranjero y comprometido con una causa ajena, a las tensiones ideológicas de los años 30. Y en tercero, señala hacia el marco de la Guerra Civil como un verdadero campo de experimentación para el ámbito de la información gráfica. Todo ello explica la fotografía desarrollada durante este periodo como el resultado del enlace ideal entre las opciones que en el ecuador de los años 30 ofrece el contexto español, la técnica fotográfica y la mirada del corresponsal gráfico. La conjugación oportuna de estas tres variables fundamentales promueve que la fotografía de la Guerra Civil Española actúe como eslabón de unión entre los principales modelos de fotografía, que son los desarrollados en las dos grandes guerras mundiales.

Por todo ello se ha planteado el trabajo de Gerda Taro como paradigmático ejemplo de su tiempo dado que la práctica fotoperiodística de esta autora radiografía idóneamente la decisiva transición fotográfica que tiene lugar durante la Guerra Civil Española. Según los resultados que ofrece este estudio, en el conjunto de sus fotografías concurren las claves de dicha transformación, fundamentales para el ámbito específico del fotoperiodismo de guerra y la fotografía de prensa. Aun así, Gerda Taro ha sido durante 
décadas una fotógrafa cuya labor apenas había suscitado mayor interés historiográfico, más allá de lo anecdótico o circunstancial relacionado con la vida de su compañero fotógrafo, en grave perjuicio de su obra. Por tanto, además de enriquecer desde una perspectiva complementaria el tema de fondo, como es la cuestión fotográfica de la Guerra Civil Española, el estudio ofrece unos resultados muy profundos que indican cómo, efectivamente, Gerda Taro contribuyó a crear un modelo fotográfico pionero que marcó los inicios del fotoperiodismo en su aspecto moderno y sobre el que se han sentado las bases del contemporáneo.

\section{Referencias bibliográficas}

Arroyo, L. B. (2010). Documentalismo técnico en la Guerra Civil Española. Inicios del fotoperiodismo moderno en relación a la obra fotográfica de Gerda Taro. Castellón de la Plana: Universidad Jaime I de Castellón.

Barckhausen, Ch. (1998). Tina Modotti. Navarra: Txalaparta

Berger, J. (2000). Modos de ver. Barcelona: Gustavo Gili.

Cartier-Bresson, H. (2011). Fotografiar del natural. Barcelona: Gustavo Gili.

Chéroux, C. (2001). Mytologie du photographe de guerre, en Voir, ne pas voir la guerre: histoire des représentations photographiques de la guerre. París: Somogy.

Faber, S. (2011). Documentando el desplazamiento: Capa, Taro, Chim y el nacimiento de refugiado gráfico moderno, en La Maleta Mexicana vol. II, Madrid: La Fábrica.

Fontcuberta, J. (1988). Fotografía documental, entre la información y la propaganda, en Agustín Centelles (1909-1985). Barcelona: Fundación La Caixa.

Freund, G. (2008). El mundo y mi cámara. Barcelona: Ariel.

Gautrand, Jean-Claude (2004). Paris mon amour. Barcelona: Taschen

Hemingway, H. (2011). Por quién doblan las campanas. Barcelona: Debolsillo.

Huyssen, A. (2002). La dialéctica oculta: vanguardia-tecnología-cultura de masas, en Después de la gran división. Modernismo, cultura de masas, posmodernismo. Buenos Aires: Adriana Hidalgo.

Knightley, Ph. (2004). The first casualty: From Crimea to Vietnam. London: Publication Data.

López, P. (2005). Historia de la fotografía en España. Barcelona: Lunwerg

Marzal, J. (2007). Cómo se lee una fotografía. Interpretaciones de la mirada. Madrid: Cátedra.

Merriam, Sh. B. (1988). Case Study research in education. A Qualitative Approach. San Francisco: Jossey - Bass. 
Newhall, B. (1983). Historia de la fotografía. Barcelona: Gustavo Gili.

Preston, P. (2005). Voluntarios de la democracia, en Las Brigadas Internacionales entran en combate. Madrid: Unidad editorial.

Preston, P. (2007) Idealistas bajo las balas, corresponsales extranjeros en la guerra de España. Barcelona: Debate.

Ribalta, J. (ed.) (2004). Efecto verdad. Debates modernos sobre fotografía. Barcelona: Gustavo Gili.

Schaber, I. (2006). Gerda Taro. Une photographe révolutionnaire dans la guerre d'Espagne. Paris : Du Rocher.

Schaber, I. (2007). During the Spanish Civil War, 1936-37, en Gerda Taro. New York: ICP/ STEILD.

Schaber, I., WHELAN, Richard y LUBBEN, Kristen (eds.) (2007). Gerda Taro, New York, ICP/ STEILD.

Serrano, C. (1987). Robert Capa. Cuadernos de Guerra. 1936-1939. Valencia: Alfons el Magnànim.

Simons, H. (2011). El estudio de caso. Teoría y práctica. Madrid: Ediciones Morata.

Sontag, S. (2003). Ante el dolor de los demás. Madrid: Alfaguara.

Sougez, M.-L. (coord.)(2007). Historia general de la fotografía. Madrid: Cátedra.

Stradling, R. (2003). History and legend: writing the International Brigades. Clardiff: Universiti of Wales press.

Torres, M. (1999). Mujer en guerra. Madrid: El País Aguilar.

VV.AA (1999). Fotografía pública: Photography in Print 1919-1939. Madrid: Aldeasa.

Yin, R. K. (1994). Case Study Research: Design and Methods. Thousand Oaks, CA: Sage Publications.

\section{Otras Fuentes}

Ce Soir, 14 de julio de 1937, portada y p. 10.

- $\quad 18$ de julio de 1937, p. 10.

El País, 29 de octubre de 2003, p. 39.

El Periódico de Catalunya, 23 de julio de 2008, p.26.

Life, 16 de agosto de 1937, p. 62.

Regards el 18 de marzo de 1937, p.6

Cómo citar: Arroyo, L.B. y Doménech, H. (2015). "Gerda Taro y los orígenes del fotoperiodismo moderno en la Guerra Civil española". Fotocinema. Revista científica de cine y fotografía, 10, pp. 119-153. Disponible: http://www.revistafotocinema.com/index.php?journal=fotocinema\&page=article\&op =view\&path[]=282

El presente trabajo ha sido realizado en el marco del Proyecto de Investigación "La crisis de lo real: la representación documental e informativa en el entorno de la crisis financiera global" (P1·1A2014-05), financiado por la Universitat Jaume I, a través de la convocatoria competitiva de proyectos de investigación de la UJI (evaluados en 2014 por la Agència per a la Qualitat del Sistema Universitari de Catalunya, AQU), para el periodo 2014-2017, bajo la dirección de Javier Marzal Felici. 